\title{
THE CORNER OF THE HORN: AN ARCHITECTURAL REVIEW OF THE LEADED MAGAZINE IN GALATA ISTANBUL
}

\author{
Namık ERKAL
}

Received: 03.02.2011; Final Text: 01.06.2011

Keywords: İstanbul urban history from Byzantine to Ottoman periods; history of the urban littoral frontier; the Golden Horn; the Fort of Galata; Castle of the Holy Cross; the Leaded Magazine (Kurşunlu Mahzen); Customhouse of Galata; Subterranean Mosque (Yeraltı Cami).

1. The first version of this paper was presented at the 1st Meeting of the European Architectural Historians Network on June 17-20 2010, in the session on Antique and Medieval Port Cities put together by chair Shelley Roff. The part on the Ottoman period has been developed as part of an ongoing work concerning the spaces of grain provisioning in Istanbul. The bibliographic research has been initiated from Eyice (1994) and Müller-Wiener (1998). I would like to thank Özgün Özçakır, who is a research assistant in METU Department of Architecture, for drafting the hypothetical reconstruction drawings.

2. The original sources will be listed in the related parts, main works which have represented the Leaded Magazine in its historical totality: chronologically due to the first publication date, van Millingen (1899); Gotwald (1907); Celal Esad (1989); Schnedier and Nomidis (1944); Mamboury (1951); Janin (1964); Eldem (1974); Müller-Wiener (1998); Berger (1994); Eyice (1994); Tanman (1994); Genim (2008).

\begin{abstract}
"Le Bruyn (...) of the seventeenth century, apologized for introducing a description of this astonishing sight (İstanbul), after the number of relations which other authors had afforded: What must then be the nature of an apology used by an Author, who, at the beginning of the nineteenth, should presume to add one to the number..." (Clarke, 1810, 686)
\end{abstract}

This article is a monograph on the celebrated site known as the Leaded Magazine (Kurşunlu Mahzen) in İstanbul: the former Fort of Galata of the Byzantine Constantinople and the Subterranean Mosque (Yeralt 1 Cami) of the present-day (1). From a typical early Byzantine defensive structure to a bastion arsenal on the Genoese fortifications, the building functioned as the northern corner of the legendary chain closing off the natural harbour, the Golden Horn. In the Ottoman period, since the site maintained its position as the maritime corner of Galata at the entrance of the port, the edifice was consequently converted to multiple forms and functions: granary, customhouse, imperial kiosk and mosque. Until 1870s the frame of the Byzantine fort had interconnected all these historical layers, however, afterwards that frame was dismantled in parts for the construction of the Offices of Public Health in such a fashion that the totality of the topographical definition became blurred. The mosque founded in the 18th century on the relics of the martyrs from the early Islamic sieges to Constantinople is one of the holiest places in İstanbul; this may partly explain the lack of archaeological work within the site. In such circumstances it is not possible to define with certainty the stratification of the existing traces of the building; however, from Byzantine historians to experts on the Ottoman city, the general tendency for the Leaded Magazine has been to accept the historical continuity of the Byzantine construction through the Ottoman conversions, rather than to suggest complete reconstructions in the successive stages of the site (2). The position of this article is in continuation with this tradition of accepting the Leaded Magazine as a multi-layered structure that can be traced as a continuous space in the original sources. Of the many titles the building had -Fort of 
3. Çiğdem Kafesçioğlu's “Constantinopolis/ Istanbul: Cultural Encounter, Imperial Vision, and the Construction of the Ottoman Capital" (2009) and Aygül Ağır's "istanbul'un Eski Venedik Yerleşimi ve Dönüşümü" (2009) can be listed as two major works reviewing the sources of the Byzantine and Ottoman period towards an innovative reading breaking the established canons.

4. In the attack of 717-18, the offending commander was Maslama, in the name of Umayyad caliphs Suleiman and Omar.

5. The names of the Byzantine emperors in English and their reigns follow the chronology in Mango (2002, 307-11).

6. Mango and Scott (1997) points to the fact that the strategy of Leo III described by Theophanes is not clear

7. Alexander Kazhdan (1998, 349-50) states that the term kastellion is not frequently used by Theophanes compared to other words used for stronghold and fortress such as kastron, and phrourion.The term fort used in the place of kastellion connotes a fortified place, a stronghold occupied only by troops.

8. Genim $(2008,20,143-4)$ states that the building was constructed by Tiberius II after an earlier text of Semavi Eyice; in a catalogue authored by Genim, "Castellion" is mentioned as one of the harbors of Constantinople, "the harbour situated just across the city in Galata" (Istanbul Ports, 2006); this identification of the Fort of Galata has not been encountered elsewhere.

9. In the Avaro-Persian siege of 626 , as Walter Kaegi $(2003,137-40)$ states, the Slavs made an attempt to attack the Port by dugout boats; however, this was not a major naval assault and there may be no reference to the Fort or the chain.

10. As far as the experts on early Islamic attacks on Byzantium are concerned, there is no direct mention of the Fort of Galata in the Arab sources related with the Umayyad sieges. However, for the second expedition that lasted seven years (672-679), the north side of the Golden Horn seems to be a

location captured for a certain period of time (el Cheikh, 2004, 60-4; Wellhausen, 2004, 31 64; Ostrogorsky, 2002, 123-4).
Galata, Castle of Holy Cross, Arsenal, Imperial Magazine, Galata customs, etc- "the Leaded Magazine" (Kurşunlu Mahzen) will not only be used as the strong architectural link between the representations of the Byzantine and Ottoman periods but this naming will also be the backbone of the article. Nevertheless, the sections are still defined after the titles and functions of the building in different periods. With the exception of the second section, which is on the present day site, the text follows a chronological order from the early Byzantine period to the late 19th century. There are recent works on Constantinopolis / İstanbul that perfectly illustrate the necessity and value of the review and reinterpretation of the familiar sources in a diachronic manner (3); this article parallels the attempt by reviewing the established canons of the Leaded Magazine.

Listing the historical functions of the Leaded Magazine in terms of architectural typology -namely military architecture or architecture of defence; spaces of provisioning and storage; architecture of custom border and surveillance- shows that these are either poorly researched topics or as for the periods that are concerned they are not among the major areas of interest. Nevertheless, all these functions are related, in one way or another, with the history of the urban littoral frontier. The origins of the Leaded Magazine as an early Byzantine Fort -a rectangular enclosure with or without corner towers- is a definite type; however, the conversion of the structure to uses other than the original function defies conventional analysis, where the building has an atypical form or an atypical function. The answer to the question whether the architectural history of the Leaded Magazine is a proof for the autonomy of the architectural form is underlined in the concluding part. However, here it should be said that there have been practical and symbolic factors behind the transformations: the fort, the undercroft, the bridgehead, the arsenal, the granary, the customhouse, the quarantine and even the mosque.

\section{THE HARBOR FORT}

The foundation date of a fort guarding the northern entrance of the Golden Horn is not precisely known; in the absence of in situ inscriptions and the scientific dating of the archaeological remains, the only reference is provided by the Byzantine literary sources. The Chronicle of Theophanes the Confessor of the early 9th century is the first salient source to mention the Fort of Galata; on the section depicting the Third Umayyad Siege (71718 ) it refers both to the Kastellion of Galata and to the chain closing off the Golden Horn (4). In this first known incident about the chain, emperor Leo III (r. 717-741)(5) is said to have opened the defensive from the Galata side as the Umayyad navy advanced to the entrance of the Golden Horn. Ironically, the offenders thinking that the open chain was a trap did neither dare to enter the inlet nor anchor on the inside of Galata (Mango and Scott, 1997, 545). This strategic anecdote in Theophanes (6) defines an upper limit for the dating of Kastellion's construction and the emergence of a topographical definition (7). Although the foundation of the Fort of Galata is attributed to the reign of Tiberius II (r. 578-582) in the anonymous late Byzantine source Patria, this evidence is discredited by many Byzantine experts as false (Mango, 1990, 219-220; Berger, 1994; 485; Eyice, 1994, 502-503)(8) regarding the fact that there is no mention of a fort or a chain demarcating the entrance of the Golden Horn in sources concerning the challenging sieges of the 7th century AD in general (9) and the first and the second Umayyad sieges $(668-69 ; 673-679)$ in particular (10). 
11. However, the restorations done by Tiberius III have not been identified as inscriptions; there are no foundation inscriptions on the Golden Horn walls predating the time of emperor Theophilos by early 9th century (Mango, 1993).

12. In the historical texts concerning his attack there seems to be no mention of a fort or a chain, unless they were intentionally not used against the Byzantine navy. There is one occasion where the chain was used against the rebel divisions of the Byzantine navy leaded by Thomas the Slav, which will be mentioned below.
Figure 1.1. The Fort of Galata and the hypothetical line of the chain of the Golden Horn, drawn by the author on the map of harbors of Constantinople of Müller-Wiener $(1998,7)$.
Tiberius III Apsimaros (r. 698-705) and his successor Anastasius II (r. 713715) are named as possible founders of the Fort, who are also noted as having restored the maritime fortifications of Constantinople (Cameron, 1980; Tsangadas, 1980)(11)against a new wave of Umayyad attacks following the taking of Carthage from the Byzantines in 695. In fact, following the upheaval of the navy in Crete, it was Tiberius Apsimaros who was declared as emperor and then had to lay siege to Constantinople for the recognition of his claims (The Oxford Dictionary, 1991). He besieged the capital city by anchoring on the Galata waterfront (Sycae)(12). If Tiberius Apsimaros constructed the Fort of Galata, it was not only the first hand experience of Carthage's defence but also his maritime offence on Constantinopolis that should have been instrumental for the project. Another possibility is the restoration and adaptation of an existing fort
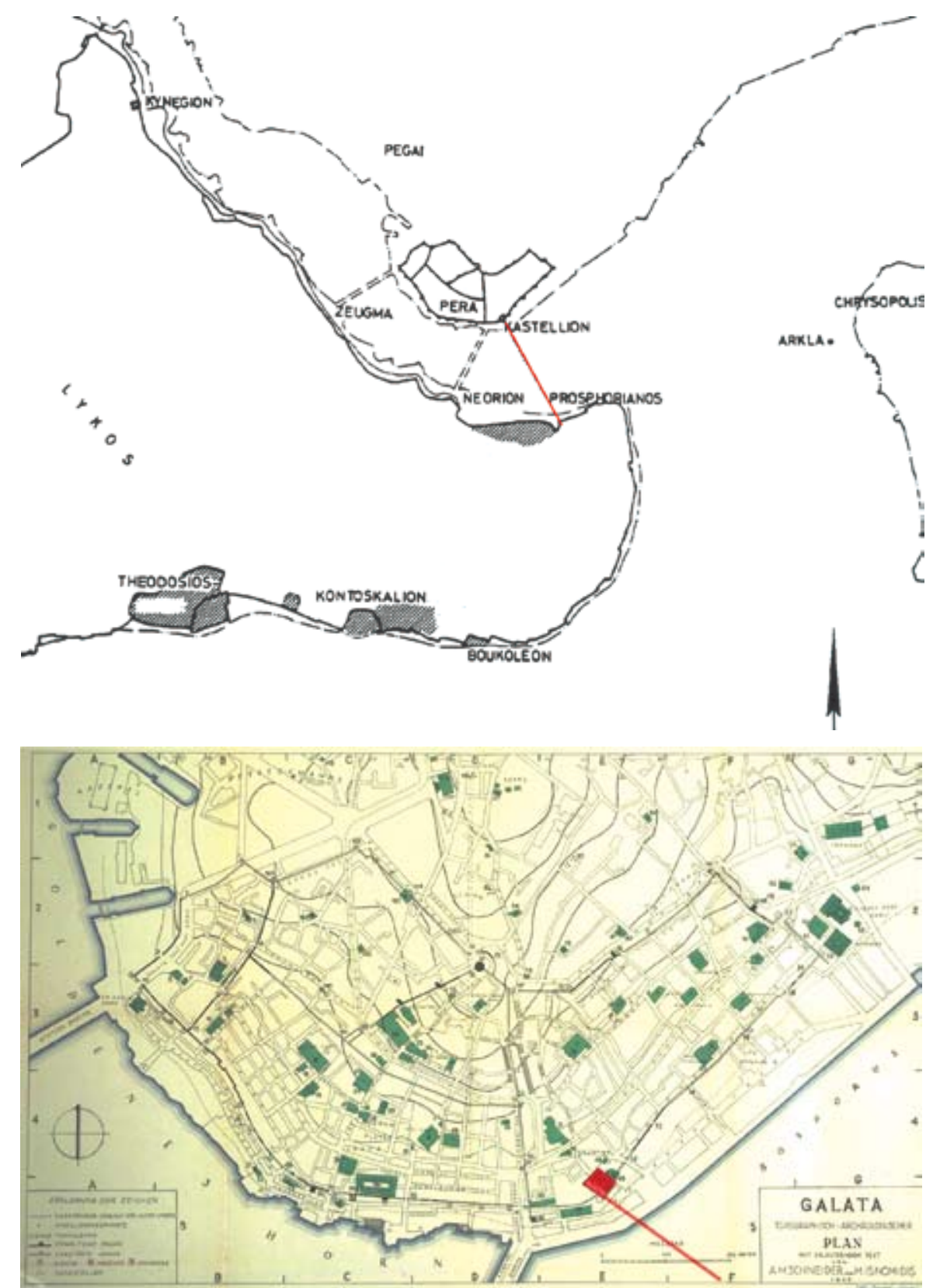

Figure 1.2. The Fort of Galata and the Genoese fortifications, the hypothetical line of the chain of the Golden Horn, drawn by the author on the archaeological map of Galata by Schneider and Nomidis (1944). 
13. Since it was Tiberius II who had finished the work started by Justin II for deepening and extending the former Julian harbour, the tower constructed by him to guard the harbour can also be that of the Sophia Harbour (Bardill, 2004, 38).

14. In another article, we have phrased the Late Antique harbours of ConstantinopleNew Rome as the New Ostia Portus in order to underline the presence of the maritime function within the imperial capital, which was different from the reserved relation of Rome-Ostia (Erkal, 2010a, 91).

15. Reconsidering the functions along the maritime neighbourhoods in Notitia Urbis Constantinopolitanae, an urban censor of the early 5th century AD, Magdalino states that the city of the period was oriented to the Golden Horn within this double structure. In our PhD Thesis (Erkal, 2001) we have debated that in the same period the city was oriented to the Marmara Sea in reference to the placement of the ceremonial axis Mese and the imperial fora with the evidence listed by Cyril Mango (1993). The article of Paul Magdalino details and challenges the Marmara orientation on the map due to the functions distributed at the skirts of the harbours found in Notitia, where the Golden Horn harbours seem more significant according to the adjacent urban functions.

16. The shock of the first wave of plague in the Mediterranean may be influencial in the shift from the north fronting shallow ports to the south facing large harbours.

17. The thesis of Magdalino is not contested and supported by the recent excavations in Istanbul; the Theodosius harbour in Yenikapı and Prosphorion in Sirkeci; for the preliminary assessments of the excavations, see, In the Daylight (2007). Theodosius harbour declined after the 7th century with gradual silting caused by the Lycos river; the Sophia harbor on the contrary, functioned as Kontaskeleon of the Late Byzantine period and the Kadırga Limanı of the Ottoman city till the 16th century; the iron gates enclosing its entrance are abstracted in the views of Schedel, in some versions of the Bondelmonti maps and Vavassore maps (Yetişkin-Kubilay, 2009).

18. Magdalino argues that it was only after the 11th century that the maritime orientation shifted to the Golden Horn side as concessions were given to the Italian maritime republics on the cheaper available land near the then in-filled Ancient harbours; see also Ağır (2009).

19. It should be underlined that the main threat in the 7th century was coming from the Marmara Sea, where the Umayyads, who resided for years harbouring around

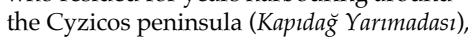
could perform unexpected incursions. The existence of the provisioning harbor Sophia and Theodosius on the Marmara Sea can be seen as a dilemma against the safe guarded navy.

20. The greek fire was first used in the former Arab siege in $670 \mathrm{~s}$. The most cited source is Riddick Partington (2004), for the new research on the topic see, Haldon, Lacez and Hewes (2006). (maybe constructed by Tiberius II) for the new device of the chain in late 7th century (by Tiberius III), which is not, however, specified in historical sources (13).

No matter whether it is the second or the third Tiberius who had the Fort of Galata constructed, in any case, the two centuries between these two emperors marks a time of transformation for the Constantinopolitan waterfront from its Late Antique harbor structure to a Medieval one, which presents an essential background for understanding the original context of the Fort and the function of the chain (Figure 1.1)(14). The celebrated historian Paul Magdalino (2000, 209-26) states that the harbours of Byzantine Constantinople -unlike those of Ottoman İstanbul- were not centred solely around the natural port Golden Horn but were respectively distributed on the Marmara Sea (Propontis): By the early 5th century $\mathrm{AD}$, there were two adjacent enclosed harbours on the Golden Horn (Prosphorion and Neorion) and two others were on the Marmara (Julian and Theodosius). On the other hand, this double orientation in maritime functions has not been symmetrical in time and in space through the Byzantine era lasting from the 5th to 12 th centuries (15). By the reign of Justinian (r. 527-565), the maritime orientation shifted to the Marmara side: the trade activities were moved from Neorion on the Golden Horn to the Julian harbour on the Marmara Sea which was later enlarged and renamed as Sophia by Justin II (r. 565-578) and Tiberius II (r. 578-582)(16). In the following century with the loss of the Eastern Mediterranean provinces to the new Islamic state, which facilitated direct attacks to the capital by the sea in the time of the Umayyads, the Theodosius enclosed harbour (mainly reserved for the Egyptian fiscal trade) began its slow decline (17). However, the Sophia harbor retained its significance, especially in connection with the new neighbourhoods developing on the Marmara seafront. On the opposite side, by the Golden Horn, Neorion was reanimated as a naval base and was cleaned of its deposited silt at the end of the 7th century, the dawn of the third Umayyad Siege (18).

The shift of the economic flow to the Marmara waterfront as proposed by Magdalino and the consequent increase in the military function of the northern inlet, underlines the function of the chain of the Golden Horn in the foundation period of the Fort as the main defensive system for the Byzantine navy, which was specifically located within the Neorion (19). When the fact of the enchaining of the city's navy base is stressed further, a partial explanation can be found for Leo III's unclear stratagem of opening the chain of the Golden Horn during the Umayyad siege of 716-717 and the ensuing hesitation of the offenders to enter the port. The Umayyad hesitation might have been related with the possibility of fronting the Byzantine navy in its own base, which would have been equipped with weapons of Greek fire (20). In any case, the opening of the chain from the Galata side is an important evidence for the role of the Fort in the maritime defence. John Pryor and Peter Wilson $(2007,384)$, whose article presents the most recent reinterpretation on the Chain of Golden Horn states briefly that:

"Almost certainly [the chain] was not run out in times of peace and used for commerce control because none of the many descriptions of Constantinople ever mentioned it, and it was only ever used when the city was threatened. Whether it was used on other occasions is unknown."

The Fort of Galata functioned as a harbour tower for the "enclosable" Golden Horn port and defined the corner of the defensible area for 
21. The 13th ward seems to be the step stone and also place of negotiation for many besiegers of Constantinopolis, we have noted Tiberius III's anchoring at Sycae, The Umayyads, Avars and Russians put their mark on the Sycae limits; the Crusaders inhabited the ward in 1203.

22. For a bibliography on the fortifications of Sycae and Galata, see Müller-Wiener (2002, 322).

23. In Antiquity, the shore, which was mentioned to be inhabited by oysters was named as Ostreodes, in reference to the $16^{\text {th }}$ century humanist Pierre Gilles (2000, 85-88) who speculated that the shore of oysters was by the church of St Clara that was adjacent to the Leaded Magazine in his time; Gilles book De Bosporo Thracio here referred after its translation in Turkish, was based on the Anaplus Bosporu of second century BC author Dionysios Byzantios; see also Müller-Wiener (2002).

24. The map of the municipality was also used by Müller-Wiener as a base for his topographical and historical survey MüllerWiener (2002); see also, Yetikin Kübilay (2009). the sector of the city across the Inlet; that is Sycae, the 13th ward of Constantinople, which had its own fortifications. The nature of the relation between the Fort with the Sycae fortifications is not clear as there are no archaeological references for the fortifications of the 13th ward, which is thought to have been first laid in the time of Constantine I (r. 306-339) and then restored by Justinian I (21). The fortifications of this sector have been referred as to be demolished by Michael VIII (r.1261-1282) in late 13th century before the area was given over as a concession to the Genoese, when the Fort of Galata was kept by the Byzantines in order to defend the port (22). As there are very few (if any) traces for the pre-Genoese fortifications of Galata, the architectural relation between the Fort and the 13th ward is not definite (Figure 1.1, 10). It has been debated that the Fort might have been connected to the fortifications of Sycae with a wall as shown in the earlier versions of the Buondelmonti map (Berger, 1992). As the predecessor of the Leaded Magazine, the Fort of Galata, whether detached or attached literally, formed the cornerstone of the defences of the north Golden Horn. The events around the foundation period of the Fort -time of an epic offense and defence- resulted with the survival of Constantinople among the new ruling centres of the Eastern Mediterranean, which were represented in later Byzantine and Islamic sources. These sources are not only important for material evidence of the Leaded Magazine, but also form the mythical background for the foundation of a mosque on the relics of Islamic martyrs following a thousand years of the assault.

\section{THE UNDERCROFT}

From the urban archaeological evidence on the site of the Leaded Magazine, it may be stated that the major surviving part of the Fort of Galata appears to be the actual foundation of the building itself, which is a raised substructure -an undercroft- that has been preserved in İstanbul as the Yeraltı Cami (literally, the Subterranean Mosque; previously known as the Leaded Magazine Mosque). The present Mosque is 50 meters inland from the sea; originally the Fort should have been on a shallow flat shore (23). In this geographical context, where there is no reference to any massive geological element like a projecting body of rock that might have been used as a natural fortification or a foundation, it is not surprising that the heavy bulk of the Fort by the waters edge should have been substructured on a vaulted crypt. In the topographical maps of Galata, such as the municipal maps of 1922 (24), it can be observed that the contour line of 2 meters from the sea level follows the blueprint of the foundation. This may either indicate that the Fort was constructed on a flat natural projection or that it was constructed over the water and formed the cape there. In fact, as manifested in the legacy of surviving monumental vaulted cisterns, crypts, and cryptoporticos in İstanbul, a groin-vaulted foundation should not be an unduly great venture for the Byzantines. However as impressive as they are, the Byzantine foundations are not sufficiently researched, as put briefly by Robert Ousterhout $(2008,118)$ : “Foundations... although they are usually the best surviving portion of medieval buildings, they are often least studied". In this respect, the undercroft of the Leaded Magazine is not an exception.

Similarly, scaled drawings of one of the most celebrated religious buildings of İstanbul, the Subterranean Mosque, are hardly ever found in the printed sources, including not only the architectural guides of the city 
Figure 2. "Public Health Administration", detail from the Municipal maps known as Alman Mavileri, 1914-1916, (Alman Mavileri, 2006, H9, H9/4).

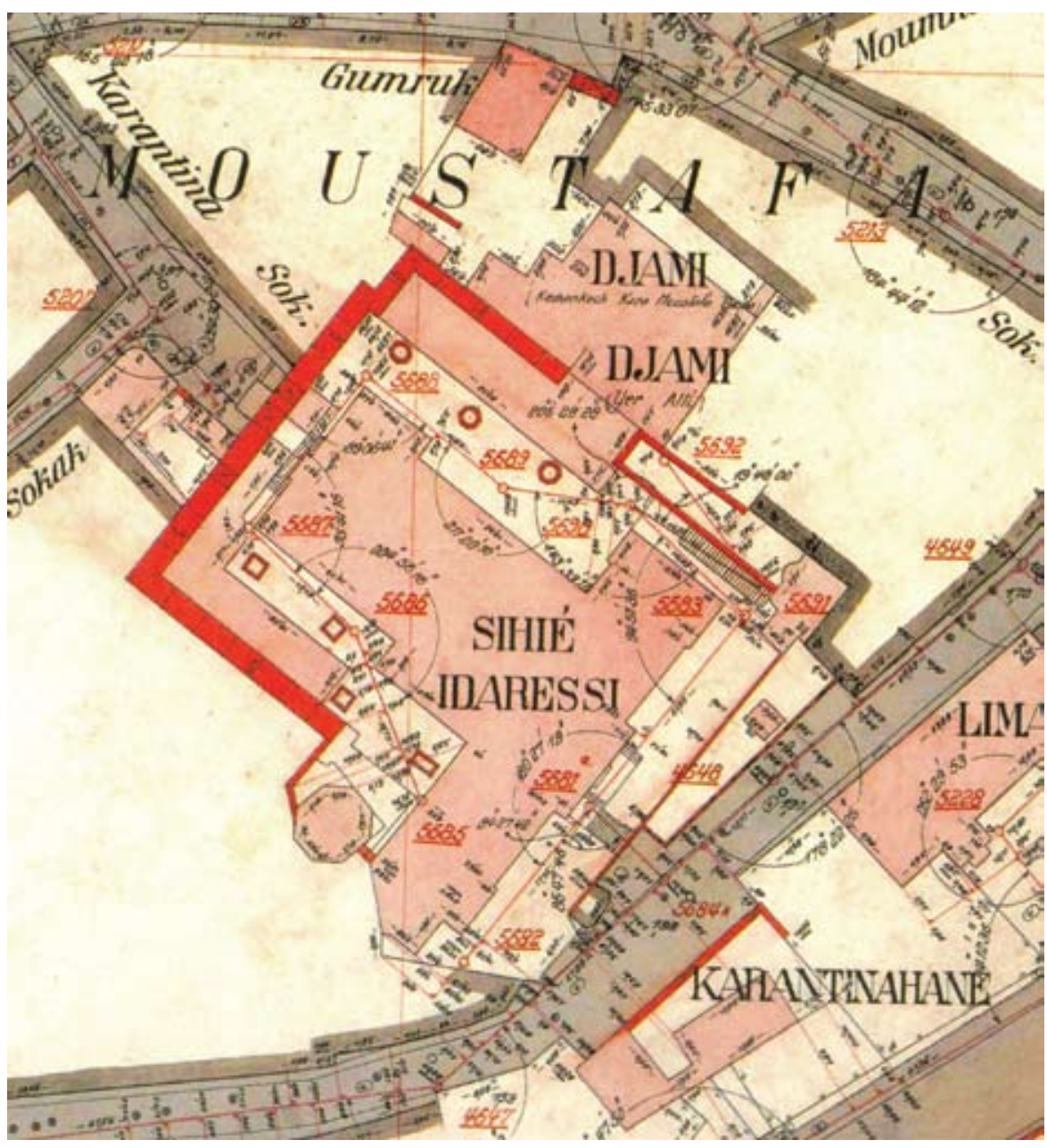

but also the books on religious architecture. The first map that depicts the exact coordinates of the roof plan of the Leaded Magazine are among the municipal maps known as the Alman Mavileri (Alman Mavileri, 2006, H9, H9 / 4) dating from 1913-14s (Figure 2). Although an unclear facsimile, the plan drawn by the renowned Byzantinist Ernest Mamboury (Fig.4) that was published in a guide of 1950s is still usable (1953, 417; Eyice, 1994). Sedat Hakkı Eldem's Kiosks and Pavilions, on the section covering the Leaded Magazine Kiosk, includes a small plan of the mosque within
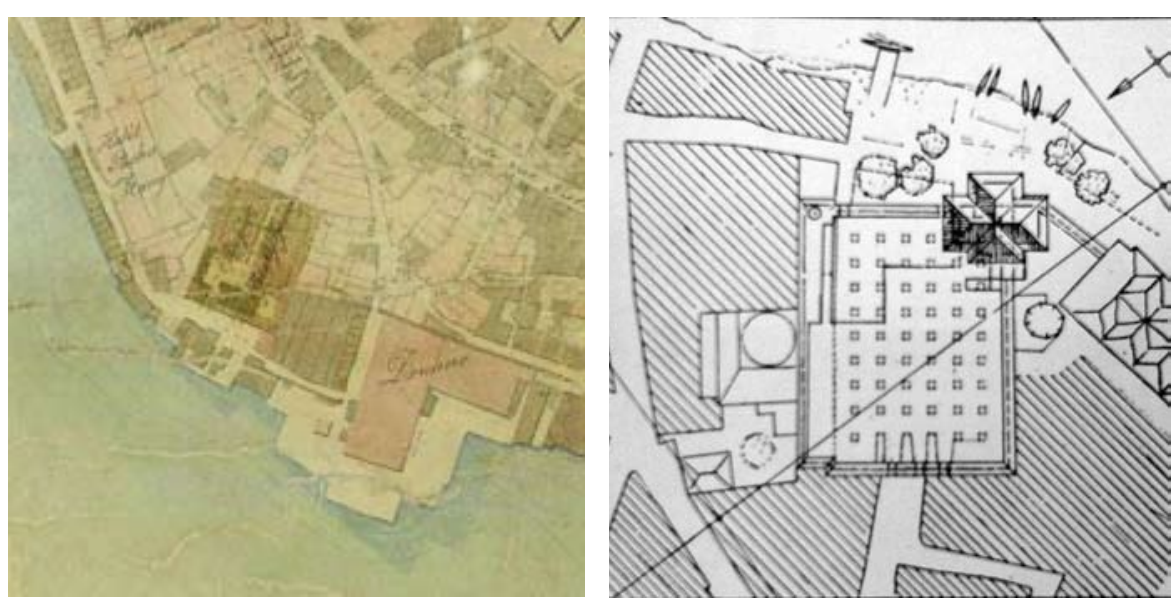

Figure 3.1. "Magazine and Yeralty Camysi" detail from the D'Ostaya map, c.1858 (IBB Atatürk Kitaplığı, no 5692).

Figure 3.2. Leaded Magazine in the mid 19th century according to the restitution by Sedat H.Eldem (Eldem, 1974, 181). 


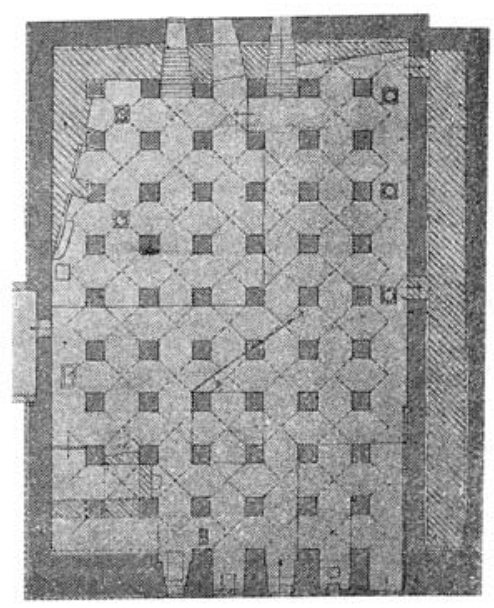

Figure 4. Plan of Subterranean Mosque drawn by Ernest Mamboury (Mamboury, 1954, 417).
25. I would like to thank architect Alişan Çırakoğlu for his help during the measurements on the site.

26. The number of the piers in the original might have changed from 54 to 63 according to the articulation of the sections, which had been closed.

27. When the mortaring on the piers are concerned the original system seems to be formed of, approximately, a $150 \mathrm{~cm}$ grid where the intercolumniation is $300 \mathrm{~cm}$.

28. The dimensions of the Fort are given by Albrecht Berger in his article on

"Kastellion", as 35mx35m (1994, vol 4, 485); it is not clear whether the author proposes a transformation in plan from a square to a rectangular plan, which could not have been followed in our work.

29. The original height might have been larger as the relation of the substructure with the sea level could have changed.

Figure 5. Interior of the Subterranean Mosque (photos by the author; 2010): a. The mihrab row; $b$. The entrance of the tomb from the fifth row; c. The mihrab axis; $d$. The Tomb Room with the well. the fabric of the 1850s (Figure 3.2) and the restitutions of the sea elevation (1974, figure 158). In this article, the data provided in these sources will be reviewed with in situ observations (25). Preserved as the prayer hall of the Subterranean Mosque, the undercroft is formed of $7+1 \times 10$ bays spanned by identical low groin vaults resting on large piers (26); today forty two piers are visible (Figure 4). The square piers are 155-170 cm thick; the intercolumniation is approximately the measure of two piers, that is 280$295 \mathrm{~cm}$ (27). Then, the present blueprint of the edifice defines a rectangular base of 34-35/43-44 meters from the interior and 38-38.5/49-50 meters from the outside (28). The walls are around 2,25 meters thick; on the northeast front it is less than two meter. The height of the vault arch is approximately the width of the pier; the top of the arch is $270-280 \mathrm{~cm}$ high (Figure 5)(29).

Where the central parts are undifferentiated forming a maze-like space in its continuous extension, structural changes can be observed within the sides, which may have been altered with the impact of the combats, natural disasters and repairs. The differentiations on the sides will be noted in
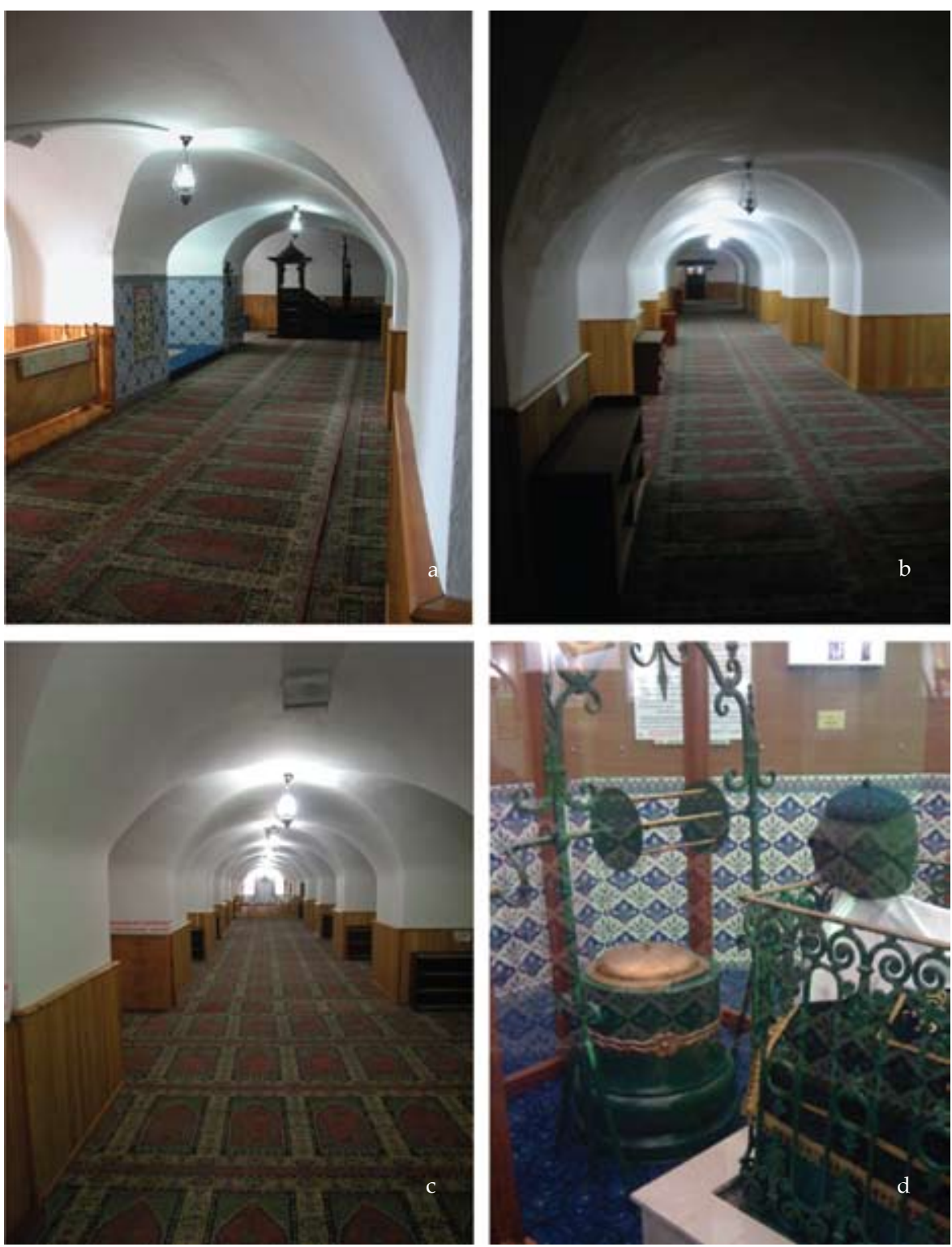

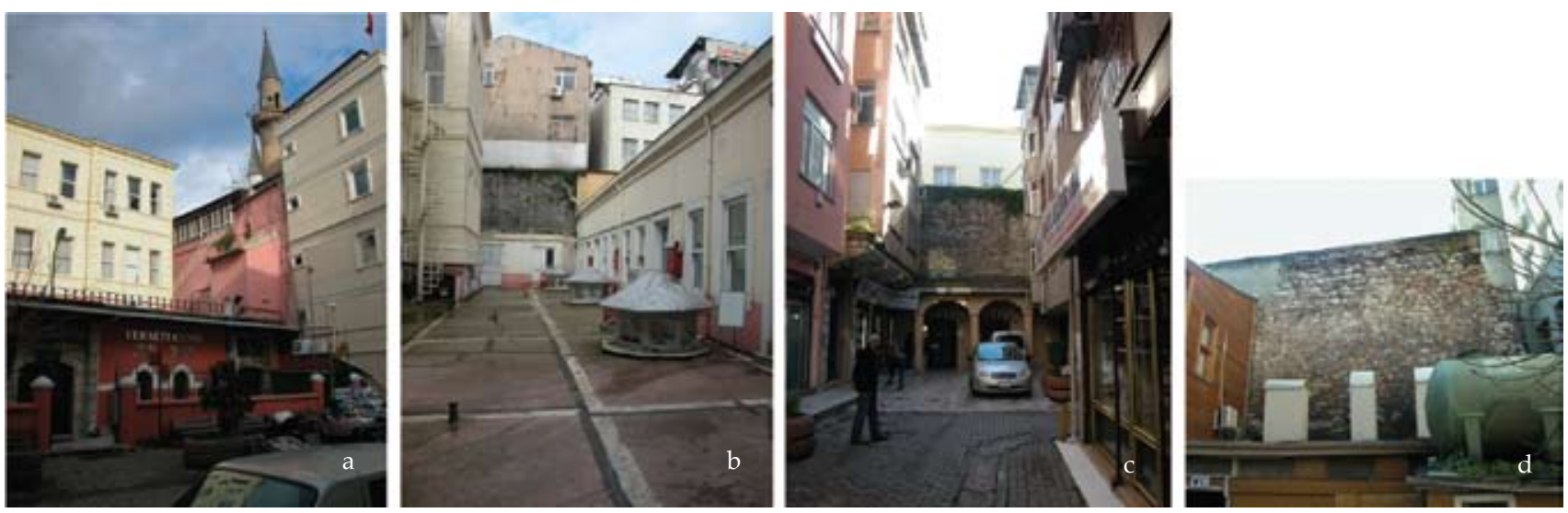

Figure 6. Walls of the Leaded Magazine (photos by the author; 2010): $a$. The front façade of the Subterranean Mosque and the Public Health Office; $b$. The terrace over the Mosque with the ventilation shafts, the grey-yellow wall at the back is the remains of the fortifications; $c$. The façade from the back street; $d$. The façade of the fortification from the courtyard of Kemankeş Mustafa Mosque.

Figure 7. Walls of the Leaded Magazine at the back of the Kemankeş Mustafa

Mosque, the red line indicates the line of the fortification (photos by the author; 2010).

30. Interventions on the northeast side are not surprising due to the fact that the front is one of the most vulnerable parts of the Fort facing a shore open to assaults from both land and sea; J. Gottwald (1907) states that in early 1900s when he visited the site, under the Kemankes Mosque he had seen pieces of building materials laid on the foundation of the wall, which may point to a restoration by spoils in this section. In the cellar of the shop under the mosque, one bay of the system can be observed under the plastic cover.

31. It cannot be ascertained whether these staircases were made before or after the conversion to the mosque.

32. This is one of the ranks of the relics of the Islamic martyrs; the change in this section might also be related with the consolidation and restoration of the corner.

33. In case the tomb is not originally built over a tower of the Fort, the octagonal room encircles a former well (maybe a hagiasma) that was left out of the defences, either

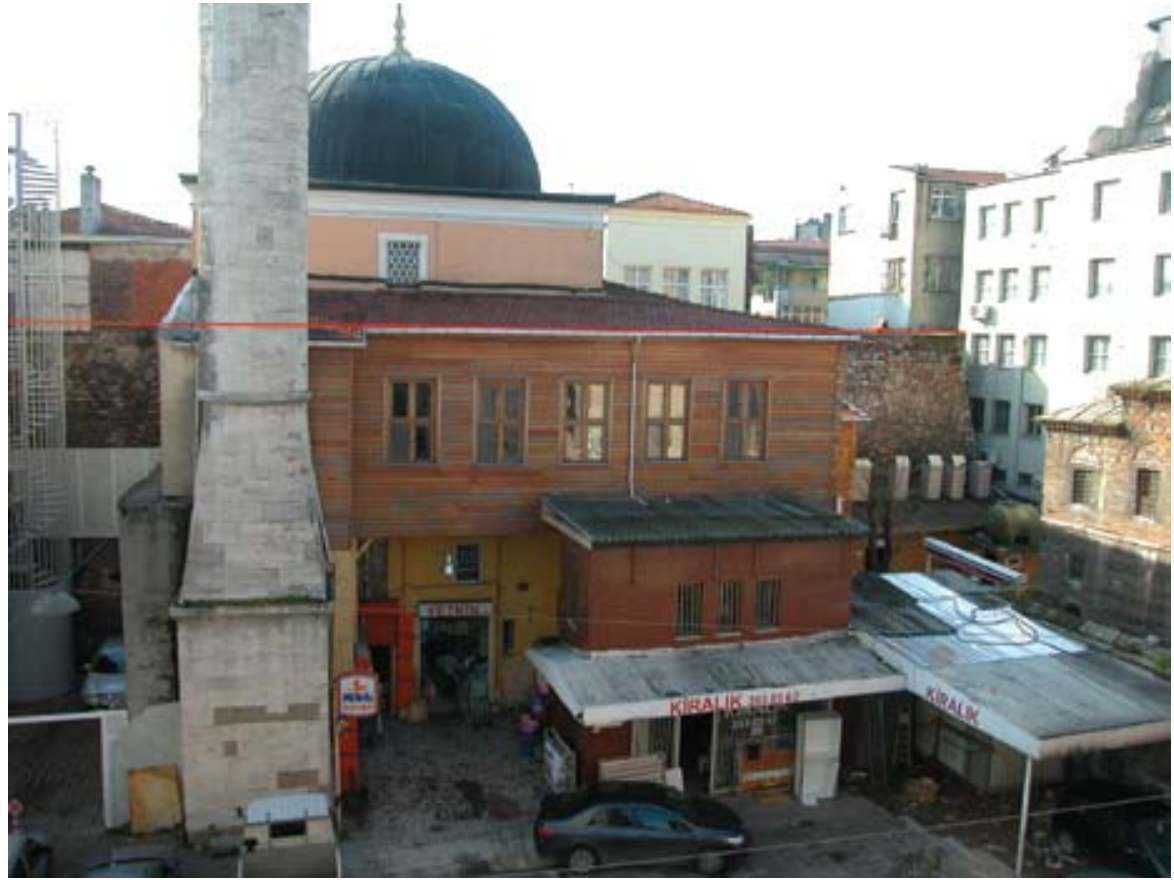

the counter-clockwise direction starting from the northeast. The row on the northeast direction is almost closed as a whole (thus, it is labelled as row +1$)(30)$. Here, the restorations may include the infill of the row or the addition of an extra axis as part of consolidations within the Fort. Turning to the northwest side, the last row in this direction, which is bisected by three staircases, is almost filled by walls; the middle leads to the terrace over the substructure while the others provide access to the subterranean hall (31). The row on the southwest side is filled with the thickness of the wall in an inclination between the fifth to the ninth rows (32). There is an opening on the southwest wall leading to an octagonal room that is a tomb chamber attached the Mosque (Figure 5). The angles of the octagon do not fit the lines of the substructure and the walls leading to the high skylight dome are irregular. Strikingly there is a water-well by the head of the central sarcophagus (33). The southeast front is different in the thickness of the piers; in fact this part might have been partially erased and partially filled in the construction of the new facade of the mosque (34). The Littoral Public Health Offices building was built over the substructure in the second half of the 19th century, which makes use of it as a continuous 
within Sycae or completely on the outside. The location of the wells outside the forts may seem a contradictory element in time of defence, however, when the space of the Fort is limited and supplementing defensive units are placed outside that location can be used by these units without direct relation with the Fort. Foss $(1996,46-8)$ gives the Fort of Philokrene (Bayramoğlu) as an example. Celal Esad mentions the hagiasma inside the Subterranean Mosque frequented by the Muslims and non-Muslims (1989).

34. Another possibility is the thickening of the piers that acted as gates at this section; the change in the south facade will be dealt in detail below.

35. The Office building has two high levels on its own sub-basement floor that is partially buried within the thick layer of flat roof over the substructure.

36. These might have been opened in the time of the construction of the Offices as before there were other structures covering the sides.

37. The brickwork of the substructure could have been partially observable in the shop beneath the Kemankeş mosque, which are within the closed bay on the northeast; this part has been covered by plastic siding in 2009.

38. On the Goad map of 1904-05, the height of the wall is noted as $35 \mathrm{inch}$; that is approximately $8,90 \mathrm{~m}$. This measure should have been taken whether from the Quarantine street or from the backyard of the office (Charles Eduard Goad, 2007).

39. Like the castle in Darıca (Ritzion) noted by Clive Foss $(1996,50)$ where the Komnenean tower and Palaeologan wall was rebuilt on an older wall foundation.

40. The battlements could have been eliminated in the 18 th century. The thickness of the walls is approximately $2,2 \mathrm{~m}$; this is a suitable distance for the walkway of a small size fort including the battlements (Foss, 1986).

Figure 8.1. Paphos Castle, Cyprus, early Byzantine defenses built over by the Crusaders.

Figure 8.2. Arched walkway from the Theodosius fortifications, İstanbul. foundation (35). The western three bays at the southeast front are covered with the stairway reaching up to the platform of the Offices. There are light wells (perhaps ventilation shafts since these do not suffice to light the space below) towards the sides of the hall, which are opened at the places free of the blueprint of the building above (36). The original building material of the substructure is concealed behind a thick layer of white paint for the vaults; additionally, there are wooden panels on the piers (37).

About one half of the fortification walls of the Leaded Magazine framing the undercroft survive towards the north, as the other half was demolished in the second half of the 19th century during the construction of the Public Health Administration offices. Without any chemical analysis or excavation, the dating of these walls cannot be ascertained. As will be detailed below, the building had been battered badly in times of siege, exploded when used as a gunpowder magazine, burnt down as a custom depot and probably gone through as many restorations. Since they have been transformed in sections according to the juxtaposition with adjacent buildings, the standing half of the fortifications cannot be observed as a continuous frame from the outside. From the inside the wall forms the backyard edges of the Office building; this face is also sided by low service structures; interior faces are partly covered with grey mortar and pink paint (Figure 6). The upper level of the walls is the same, where the height changes on the street sides due to topographic differentiations; the highest point in the present seems to be over ten meters from the exterior (38). The mixed brick-stone masonry of the walls is visible only at the outer sections on the northwestern street façade (Karantina street) and partially on the side of the Kemankeş Mustafa Mosque (Figure 6, 7). The coursework in northwestern side is altered with modern concrete mortar, where it is no longer possible to differentiate the original brick courses. The northeastern facade at the Kemankeş Mustafa Mosque courtyard and the adjacent Bank office building's backyard display a continuous coursework with careless construction, an example of the "mortared rubble with small bits of brick surrounding stones". This type of brickwork is elsewhere identified by Clive Foss $(1996 ; 1986)$ as Kommenian or Late Byzantine style. However parts of it can also be partially an Ottoman repair.

Another feature of the eastern wall carrying late period interventions, is the change in the northeastern corner where the wall is set back in plan but is purposefully inclined towards the bottom in one direction (Figure 6). This point is particularly important, as it is the only visible corner of the Fort, where there is no corner tower. On the other hand, the alteration of the wall also brings forth the possibility of transformation including the demolition of corner towers. The repair of wall sections in castles and fortifications in the Byzantine period is not rare (39); the visible sections of walls of the Leaded Magazine at the north-east and north-west give preliminary clues
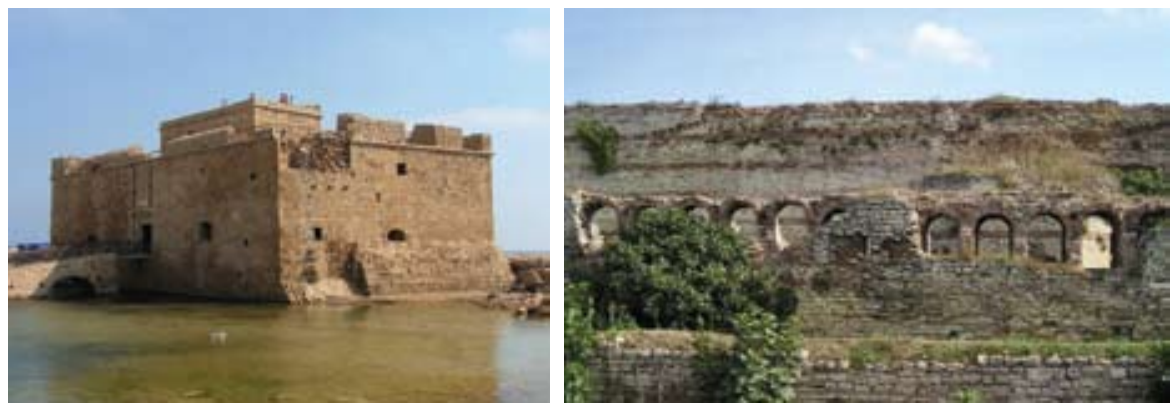
41. The tower/s attached to the building after the 13th century will be debated below.

42. Not to be confused with the standing great tower baring the same name, the Fort was also called as the Tower of Galata.

43. No matter how the sizes vary, the Byzantine typology of the quadrilateral fort still dominates among harbour examples when the site does not enforce an organic plan. For a larger harbour fort than the one in Galata, the Byzantine fort within the castle of Kyrenia in Cyprus can be mentioned, which is legible in plan, measuring nearly $80 \mathrm{~m}$ at the long side with small corner towers. The fort in Paphos, again in Cyprus is very much altered but depicts a smaller example of a fort on water constructed over an elevated substructure. The dimensions of the Galata Fort conform with an inland Byzantine castrum, that is the outer walls of the crusader Castel Rouge, also known as Qalat Yarmouk (Nicolle, 2005a)

44. In the text, Kastellion is referred as in Bosphorus which is a wider geographical definition including the inlet. Another chain is known to be stretched to the Maiden Tower by the Bosphorus in a later period; there are some researchers who think an earlier date for the Bosphorus chain.

45. Tsangadas (1980) states that Theophilos restoration work along the maritime fortifications is marked by many inscriptions, such that these were taken as an evidence for the questioning of a pre-Theophilos fortification in the Golden Horn apart from the walls of ancient Byzantion (Mango, 1993). Nevertheless, there are other emperors who are referred to restore the maritime fortifications prior to Theophilos; Tiberius III Apsimaros and Anastasius II have been credited for the first major restoration of the maritime defences.

46. For the Russians, attacking the Golden Horn was not an artifice but a natural strategy as they were assaulting the city by taking the down stream of the Bosphorus, which at least on two occasions is known to be enchained against their forces.

Nevertheless, Russians did not succeed to cross over the defensive. The Russians attacked Constantinople at least on three times, however in 969 which Leo the Deacon mentions the precautions, there was not a direct attack but an assault on Thrace as a whole. The first Russian attack was in 860 (Vasiliev, 1948); the second attack was in 907 that of Oleg, which is not directly referred in the Byzantine sources, but in the Russian Primary Chronicle, where the chain and Galata is mentioned openly (Vasiliev, 1951, 163-225). The third attack was in 941 under Igor of Kiev, where there is no mention of the chain but of the 15 retired ships with greek fire managing to keep out the Russian flotilla at the entrance of the Bosphorus (Obelensky, $1994,56)$. The fourth wave of attack is around 967- 970; when in 969 Nikephoros Phokas enchained the Golden Horn. The last attack was in 1043 where the Russian fleet was defeated by the help of Greek fire on the Anatolian side.

47. As the Tower was in close proximity to the Gate of Eugenius by the Prosphorion, a major point of access to the former for a considerable repair. The demolished southeast façade is represented in the visual documents of the Ottoman period that will be mentioned below (Figure 7). There is no evidence for the walkway of the Fort over the walls or battlements; there is a continuous brick capping on the existing sections (40).

In summary, the undercroft defines a typical medium size early Byzantine fort plan demarcating an open enclosure on top without any central structures. There might have been galleries around the perimeters of the upper enclosure; there are no traces for small round corner towers (41). In fact, since the Fort was also named as phrourion or pyrgoma (Eyice, 1992) (42) it might also have been comprehended as a large harbour tower. On the other hand, no matter how clear the scheme of a rectangular fort/tower with or without round corner as a typical Byzantine defensive structure is, it is almost impossible to find an unaltered example. The basic reason is that the early Byzantine harbour forts constructed for defence against Umayyad excursions, like the ones in Acra in Israel, Tripoli in Libya, Kyrenia and Paphos in Cyprus, Rhodes, Heraclea in Crete and Marmaris in Turkey are usually built over in the later periods (Figure 8.1)(43). With the addition of bastions and donjons in the Medieval period the early Byzantine fort enclosures are generally infilled with new structures, where they form one of the inner or outer rings of defence. The construction of the new defensive structures alters the substructures consequently; a preserved substructure beneath a Byzantine Fort, such as the Leaded Magazine in Galata, is a rarity.

R. Ousterhout (2008) states that, withstanding the ones used as cisterns, Byzantine substructures, however spatial they may be were generally not given specific functions. Was this the case for the Forts, however, where space is a great commodity? If the undercroft of the Leaded Magazine constitutes one of the few surviving examples of the early Byzantine harbour fort architecture, then, the question should rather be why it was not much altered or what function did it have apart from being a foundation so that the space survived in the successive restorations? Might there be any other function of the undercroft that is specifically related with the basic function of the Fort -that is enchaining the Golden Horn- is the topic of the next part.

\section{THE BRIDGEHEAD}

The 10th century chronicler Leo the Deacon mentions the two ends of the chain "fastened to enormous logs" as the tower of Kentenarion on the side of Constantinople and "a tower of Kastellion" on the northern shore of the Golden Horn, which was secured as part of the preparations by the Emperor Nikephoros II Phokas (r.963-9) against a possible Russian assault from the Black Sea (Talbot and Sullivan, 2005, 48, 129-130)(44). Between the Umayyad sieges and the first Russian attack in 860 , the chain was stretched only once against Thomas the Slav (ca. 760s - 823), who rebelled with claims on the throne and besieged the capital city in 821 . After the intrusion of Thomas the Slav and an earthquake, emperor Theophilos (r. 829-842) restored the fortifications of the Golden Horn extensively (45). In 860, the Russians emerged as the new threat against Constantinople, who attacked the city from land and sea with small river vessels in great numbers; they continued their offense on the Byzantines at intervals until the mid 11th century (46). In fact, as Nikephoros the Patriarch tells in his "Short History", even before the raids from the north, it was the icebergs from 
Acropolis, that was also named as the Tower of Eugenius. The tower should have been located along the ancient fortifications of Byzantion (Tsangadas). The eastern end of the possible trace of the Prosphorion harbour's outline was displayed in the 19th century maps prior to the demolition of the fortifications at this section during the construction of the railway (Kuban, 1996, 20-1). The trace of the port pool can be seen in the map of Mühendishane1848, map of Stolpe done in 1858 but published in 1863. In the 1882 map, it can be seen that the wall has been demolished.

48. There is no exact reference for the restoration of the Tower of Kentenarion in time of the building of Kastellion, however, Tiberius Apimaros' consolidation on the maritime defences in the late 7th century could have included the south end of the chain likely.

49. The name Kentenarion can be related to the defensive function of the Tower as it is the name of a certain army division, but it may also be related to a quintal (a weigh measure of a hundred), as well as to a large weighing scale or steelyard. As Wolfgang Müller-Wiener underlined $(1998,6)$, the harbour of Proshorion was mentioned as the place of all useful things in a building census of Constantinople dating to the early 5th century $\mathrm{AD}$, where important warehouses of grain were situated and a grain market was located. Then, it can be speculated that the name Kentenarion is interrelated with a measure of grain at the Prosphorion.

Figure 9. "Fire-bearing Triremes" from the episode on the siege of Thomas The Slav in the manuscript known as Madrid Skylitzes, late 12th century (From Byzantion to Istanbul, 2010, 216). the Black Sea that fronted the Golden Horn in the winter of 763-764 when people crossed the sea from the Acropolis to the Fort of Galata by walking (Mango, 1992, 149, 219).

The concise description found in Leo the Deacon is significant as defining the exact track of the chain of the Golden Horn for mid 10th century (Figure 1). Moreover, in between the lines of the passage, here referred after its transcription, an interesting point is the mention of "a tower" of the Kastellion. This could be accepted as a reference for the possibility of the Fort having towers before the Genoese period. Yet, without any exact data supporting this clue, here, the Tower of Kentenarion can be briefly mentioned for comparison as it formed the southern bridgehead of the chain on the maritime fortification walls of Constantinople. The tower may have formed the easternmost point of the Prosphorion, the oldest port of the city (47). Tsangadas (1980) states in reference to Patria that it is Constantine I (r. 313-338), who had the Tower constructed as a great and useful edifice; the Constantinian tower was destroyed by an earthquake and was rebuilt in a smaller scale as a regular tower in the reign of emperor Theophilos by the middle of the 9th century (48). The factual knowledge on the architecture of Kentenarion is even more limited than that of the Kastellion (49). Many scholars define its location as the site of the Ottoman Basketmaker's Kiosk (Sepetçiler Kasri) along the outer walls of the Topkapı citadel, which is used as the Press Center in the present (Müller-Wiener, 2002; Pryor, 2007). Gülru Necipoğlu (2007, 298-299) in her seminal book on Topkapı Palace, mentions that in the place of the later Basketmakers', was a Kiosk called the Qasr-ı Kule, or the Kiosk of the Tower, which was an edifice comprising a single room and a stairway, probably functioning as a watch tower for the Harem of the Sultan during the navy processions. The Tower is depicted in visual sources predating the 17th century as higher than the neighbouring fortification towers where the kiosk is seen beneath a leaded pyramidal pinnacle (50). The archaeological research at the foundations of the Sepetçiler Kiosk is essential for further interpretation

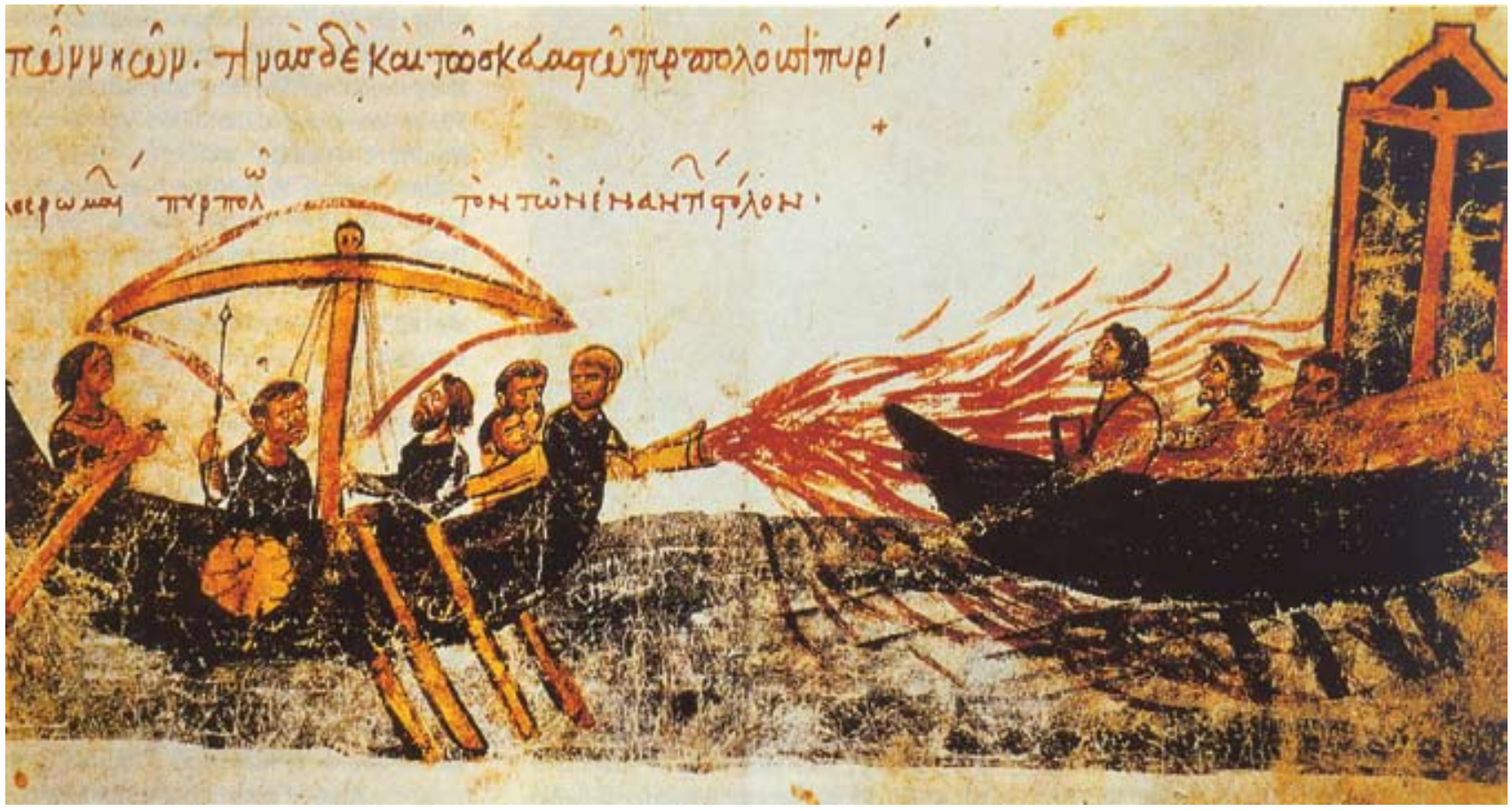


50. Necipoğlu noted the views of Lorichs, the panorama of 1590, and most specifically the panoramic view of George Sandys of early 17 th century.

51. The site of Kentenarion could have shared the function for housing the instruments of the chain with Kastellion; the location of the Ottoman palace docks at the same site is a significant continuity.

52. Before this review the article of $R$. Guilland (1959) was unchallenged as the main reference on the Chain.

53. Pryor and Wilson $(2007,379)$ state that the two preserved chains from the $14^{\text {th }}$ century that of Marseilles and Pisa has links of similar dimensions to the parts of the chain exhibited in Istanbul; it is further said that they are "fairly confident that the dimensions of such chains were fairly standard around the Mediterranean".

54. In the siege of 1453 , the location of the ships at the back of the chain is clearly known, as these ships had the new technology of the cannon, the Ottomans had not tried to assault the chain but tried indirect ways to enter the harbor.

55. The fort was defended by "mercenary troops, the English and Danes of the elite Varangian Guard, Pisans, perhaps Genoese and others" (Madden, 2000, 117), which were supported across by forces from Constantinople.

56. After the Fort was taken, it is noted by many witnesses (both from the Crusader and Byzantine side) that some of the defenders escaped from the Fort by sliding over the chain to Constantinople or by the boats.

57. The breaking the chain of the Golden Horn should have a symbolic importance as some parts of it was taken as a relic to the port of Acre, the main maritime base of the Crusaders. Chaining the port entrance was a strategy that the Crusaders themselves used in the Levant.

58. The Madrid Skylitzes (Biblioteca Nacional, vitr.26-2) is a twelfth-century illustrated version of John Skylitzes' chronicle the Synopsis Historion, which covers the Byzantine Empire throughout the years 8111057. However, another article, John Pryor $(2006,106)$ point to the unreliability of the images of ships in the manuscripts.

59. Images of Buondelmonti, Matrakçı Nasuh and Dessonville will be reviewed below.

60. The width of the bays in the under croft was $3 \mathrm{~m}$. at most, which in a regular proportion for a dromon ship of $30 \mathrm{~m}$. long. For the dimensions and proportions of the Byzantine dromon, see Pryor (2006). The length of the interior can house two ships of $20 \mathrm{~m}$. in each bay; proportionally the width should be $2.5 \mathrm{~m}$. Then the substructure could house approximately 14-16 ships.

61. As far as this research is concerned there is no source to mention the use of chain during the Latin Empire (1204-61).

62. For an interpretation of the Buondelmont maps from the Byzantine to the Ottoman era, see, Kafesçioğlu (2009,143-59). of its relation to the Kentenarion Tower. Here another feature of the area should be underlined: the waterfront by the Sepetçiler Kiosk at the Ottoman period was the place where the imperial barges were housed, this is the case at least since the reign of Beyazid II (r. 1481, 1512)(51).

John Pryor and Peter Wilson $(2007,369-384)$ re-evaluated the issue of the chain of the Golden Horn, specifically around the events of the 4th Crusade in 6-7 July 1203 by studying the remains of the chain and reviewing the textual sources (52). As an expert on pre-modern naval technology, Pryor compares the sections of the chain from 1453 preserved in İstanbul with other medieval port chains and states that, given the medieval standards of thickness, it is a major challenge to understand how the chain was stretched and kept stable at the $750 \mathrm{~m}$. width of the Golden Horn (53). At a sea depth of $44-45 \mathrm{~m}$. in the middle course, such a chain, even over large floating logs, would still fail to block the big ships that could easily pass over it. Thus, Pryor and Wilson proposed, with historical evidence, that in order to consolidate and complete the defensive strategy, the chain was backed with ships carrying siphons of Greek fire (fire bearing triremes, Figure 9). In the notes of Talbot and Sullivan's transcription of Leo the Deacon there is a point that reinforces Pryor's argument: "Notably in two instances Leo indicates that these 'fire bearing triremes' must be ballasted, a piece of information we have not found elsewhere. Presumably these ships had to be securely stabilized in order to perform this specific function" $(2005,40)$. This must be a reciprocal system; the chain was a ballasting tool for the ships at the depth of the Golden Horn, and the ships were fencing back the chain forming a ballistic trajectory of Greek fire siphons (54). Furthermore, some of the references of the 1203 siege -like Bernard the Treasurer, Robert Clari and Hugh of St Pol- speculate that the fire bearing ships and the chain on logs formed a floating bridge between Constantinople and Galata.

The events of the 1203 siege when Crusaders managed to open the blockade by taking the Fort of Galata, gives important clues on the edifice itself (Madden, 2000 117-8): After landing on the suburbs of Sycae, the Crusaders set their siege machines at the slope behind the Fort inhabited by the Jewish merchants and attacked the heavily defended building (55); the land offence supported by mines was backed by ships bearing petraries. The defenders made sorties out of the Fort. However when the Crusaders managed to take the gate, the defenders were not able to return to the building; they were obliged to leave the scene over the chain and the ships (56). Thus, as the chain was left without the support of the ships, it was symbolically "passed over" by the armada of the fleet called Eagle (Madden, 2000, 118)(57).

Unfortunately, neither the point where the chain was connected to the Fort nor the place of the gate mentioned in the sources can be ascertained. However, working on the sections of the chain, Pryor and Wilson thought that it had to be stretched to a high spot within the Fort and it had to be sliding. If as they argued "without ships behind the chain is irresistible", then, how many ships were used to bridge and consolidate the $750 \mathrm{~m}$. opening between the two towers? In the Russian attack of 941, fifteen ships with Greek fire were enough to stop a large number of small vessels; however the dimensions of the ships cannot be ascertained. Were they Byzantine dromons (long ships with two banks of rowers and two or three masts) or were they smaller ships (Pryor and Jeffreys, 2000)? According to the depictions of the fire bearing ships in visual sources, like the celebrated image of the attack of Thomas the Slav in an illustrated copy of Skylitzes' 

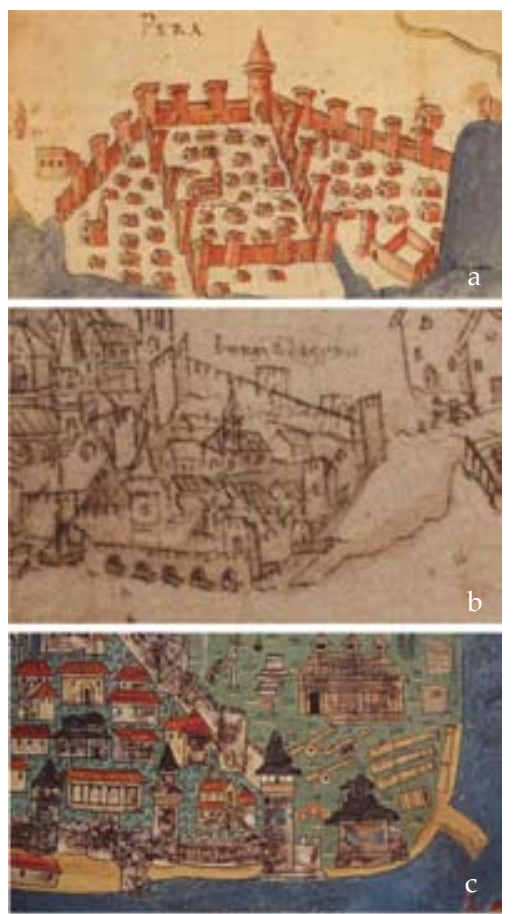

Figure 10. Depictions of the Fort of Galata from 1420 to 1537 , comparative analysis by the author: a. Map of Constantinople, Christoforo Buondelmonti, cir. 1420-1430, original in Biblioteca Nazionale Marciana, here after From Byzantion to Istanbul (2010, 244). b. Detail from Map of Istanbul, Dusseldorf copy of the Buondelmonti, cir. 1480s, Kafesçioğlu (2009); c. Detail from the map of Istanbul by Matrakçı Nasuh, 1537, original in Istanbul University Library, here after Yerasimos $(2000,131)$.
63. The tower of Traverios is interpreted as one of the standing towers of the demolished walls of Sycae; however, both the naming and the location is not clear.

64. Such as the Vatican copy dating from 1480 or the copy in Marciana Library in Venice; see Kafesçioğlu (2009, 146-7). book in Madrid, they seem to be small boats with a small crew (Figure 9) (58). The positioning of the ship, in other words whether it was decked from the side or the prow, and the technique of the Greek fire siphoning should also be significant. In addition the consolidation of $750 \mathrm{~m}$. by ships siding the chain on floating logs necessitates a space for storage; that is the case for the ships as well as the equipment. The Neorion, the center of the Byzantine navy after the 7th century was not far from the chain. In many views depicting the Leaded Magazine in the Ottoman period, before the conversion of the undercroft to the Mosque, there are arched openings shown on the ground level by the waterfront (59). The gates could correspond to the cannon holes opened in the late Byzantine period, but if they are from an earlier date could they point to the use of the area as a storage area for the equipments and tools of the chain? Not withstanding the storage of the chain and logs, could this space have been used as an arsenal, a dock for smaller ships? (60) These are open questions for the restitution of the edifice pictured only after the 15th century but described in writing much earlier.

\section{THE ARSENAL}

The 4th Crusaders' offensive to Constantinople that began with the fall of the Fort of Galata and the breaking of the chain; ended dramatically with the taking of the city by the Franks and their Italian allies (61). It was in 1261 that emperor Michael VIII Palaiologos (r. 1259-1282) managed to win back the Byzantine capital. In restoring the trade concessions with the Italians, Michael VIII preferred to settle the Genoese at the north of the Golden Horn, at Sycae; the area was assigned after the Byzantines were moved and the former fortifications of the region were demolished. If not earlier, it was then that the Fort of Galata was left free-standing however it still preserved its function as a Byzantine military base guarding the entrance of the Port and the bridgehead of the chain. In the 1303 chrysobull defining the area of the Genoese settlement in Sycae, a zone of no building, was defined around the Byzantine Fort (Mamboury, 1924). After the 1310s the Genoese started to construct their own fortifications and from this date to 1440s, the limits of Galata were extended at six different stages (Figure 1.2). The Genoese called this Fort "the Castle of Holy Cross" and as early as 1420 it already started functioning as the arzana, probably a magazine of guns and gunpowder, as well as the storage of the chain.

These transformations, which continued until the free-standing Fort became a fortification tower, can be partially observed in the different editions of the Buondelmonti map from the 1420s to the 1480s (Figure 10) (62). It was in the chrysolbull of 1352 that the area of extension between the Genoese settlement and the Fort was divided by a trench that ended in the north at the tower of Traverios (63). The definition of the 1352 charter can be seen in the earlier versions of the Buondelmonti map (64) where the Fort is depicted as a rectangular enclosure with battlements in the open waterfront connected at the back to a free standing tower; the ditch is also depicted as filled with water. Furthermore, in most of the versions there are arches drawn at the port side and the back of the rectangular enclosure.

The final mark of the Genoese expansion was the fortifications built by the waterfront of the Eastern sectors around 1440s, when the Arsenal emerged as a bastion. The fortification walls were attached to the rectangular fort at a point close to the middle in the East; the part left in the interior was comparatively longer and on the West side the exterior part was greater. 


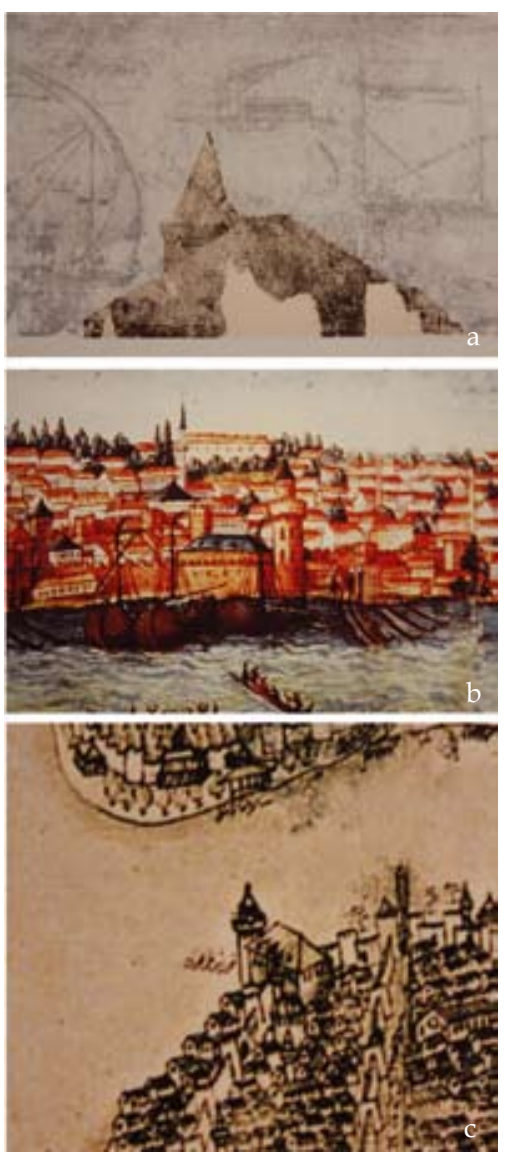

Figure 11. Depictions of the Leaded Magazine from 1559 to 17th century, comparative analysis by the author: a. Detail from the View of Melchior Lorichs, the contour of the Leaded Magazine marked by the author, original in Leiden University Library, here drafted from Oberhummer (1902); b. Detail from the View of Istanbul, 1590, anonymous, original in Austrian National Library, Codex Vindobendensis; c. Detail from the map of Istanbul in 17th century copy of Piri Reis Kitab-1 Bahriye, original in Berlin Library, here drafted after Necipoğlu (2002).

65. Eremya Çelebi, (Andreasyan, 1988, 225-6) notes that a woman called Mariette was the donor of the church; this place was well-known for an icon of San Antonio with healing powers.

66. As Pierre Gilles (2000) referred to it in the 16 th century.

67. The tower of the Holy Cross was not depicted in the earlier versions of the

Buondelmonti map; in the Düsseldorf copy there is a tower that is similar to the Tower, which is not represented at the waterfront. but within the enclosure of the Fort. Another significant map is a copy with an Ottoman Turkish legend, in National Library Paris; Kafesçioğlu $(2009,154)$.
These walls (from Karaköy to Tophane) had been constructed without any regular towers. A section can still be witnessed at the point of conjuncture with the Fort wall beneath the minaret of the Kemankeş Mustafa Mosque, which is thinner and lower than the Fort's wall itself. A gate was opened on the northeast side of the Fort and named as the Gate of St. Antonio. The name came from the church dedicated to Santa Clara in 1390 (also known as San Antonio and San Nicola), which was probably located in the place of the Kemankeş Mosque (65). The gate was also referred as the Holy Cross after the fort and as "catena" after the chain (66).

The major Genoese contribution on the site seems to be a high round tower constructed at the southeast corner of the Fort that was also named as the Tower of the Holy Cross (Figure 10, 11). However, it cannot be ascertained whether this was restored after an existing corner tower or not. In the versions of the Buondelmonti map drawn after the Ottoman conquest, specifically the Düsseldorf copy (Kafesçioğlu, 2009, 149), the Fort is only visible as part of the Galata walls; the arches at the ground floor are depicted as gates for cannons (67). Within this organic pattern of growth the Fort of Galata, or the Castle of the Holy Cross as called by the Genoese, was transformed from a free-standing Fort to a bastion within the maritime fortifications, specifically marked by the Tower of the Holy Cross, which might have been the greatest fortification tower of Galata after the Galata Tower proper. When the Ottomans besieged the Byzantine capital in 1453, it was the Genoese Soligo who was given the mission of stretching the Chain on the 2nd of April and as noted above the Genoese ships with artillery backed the defence line (Pertusi, 2006). What was then the position of the chain and the bastion or the Tower of the Holy Cross? If the cannons shown in the representations of the Ottoman Leaded magazine were already there in the 1440s, then, the chain should be stretched at a section of the bastion to the west of these cannon holes as they were to be used against the outsiders.

\section{THE GRANARY}

The Ottomans captured Constantinople; the Genoese Galata surrendered. The Fort of Galata that was a Byzantine property within the Genoese colony was taken into the Ottoman imperial ownership as a bastion. The chain had never been used in the Ottoman period, however the bastion retained its late Byzantine usage as a magazine. The Mahzen-i Sultani (literally the imperial magazine) noted in the endowment deeds of Mehmed II is generally accepted to be the former Fort of Galata (Ülgen, 1939). The building was used as an arsenal for the storage of gunpowder at a close distance to Tophane that is the cannon foundries established by Sultan Mehmed. In the versions of the Buondelmonti map from the Ottoman period, cannons are depicted in front of the Magazine. The Ottomans placed cannons on the accesses of the Port at strategic points: by the Topkapi Palace shore before the Tower Kiosk; on the Maiden Tower islet, on the Tophane square and on the Magazine (68). Although mostly used as warning signs for the passage of unauthorized ships and regularly fired for the ceremonies (such as the greeting of the navy) the trajectory of the modern cannons replaced the former defences of the Golden Horn; specifically in between the Topkapı shore and the Magazine at Galata, the line of the chain was regularly demarcated by the cannon balls.

In early 1500, lightening struck the Imperial Magazine, the stored gunpowder exploded and a big stone block that broke off from the "tower 
68. For the gunpowder industry and its spaces in the capital city see, Agoston (2009).

69. The information is given by Koçu is from the history of Silahdar. Ayşe Hür (1994, (2) 407-408) states that the fort that was used by the Byzantines and the Genoese was totally demolished after the explosion and the Fort of Galata was at the place of the Sea Terminal in Galata, both assertions are incorrect; Celal Esad (1989), on Kurşunlu Mahzen mosque, states in reference to Scarlatos Byzantios that the place known as the magazine was ruined after the explosion.

70. Matrakçı Nasuh map of Istanbul from 1537 depict the bastion/magazine by four or five opennings on the sea fortifications between two round towers. Another important point in the Matrakç view is that a wall perpendicular to the sea closing off the relation of the stretch of land that functions as the port of Galata and the seafront of the Magazine.

71. The buildings of Sinan are described in three seperate books; Tezkiret'ül Bünyan, Tezkiretü'l Ebniye both by Sai Musafa Çelebi, and Tuhfet'ül Mimarin; these books with reference to their different copies have been edited and translated to English by Howard Crane and Esra Akın (2006); in the architectural history context it was Kuran (1988) who initially published the list; see also Sai Mustafa Çelebi: Yapılar Kitabı (2003, 185)

72. There is a heading in the Autobiographies reserved for "magazines"; in different versions there are 6 to 10 buildings noted in this heading (Crane, Akın, 2006). The one at the Galata corner is noted in some version as the grain magazine, where the Leaded Magazine in Tophane does not have any specified item.

73. An example for the case of duplication can be the Subaşı Süleyman Mosque in Unkapanı, which was originally built by Sinan and then rebuilt by the Master after a fire.

74. The view is formed of three parts each showing sectors of Istanbul from the sea level in perspective that are Istanbul, Galata and Üsküdar; Austrian National Library, Cod. $8628^{*}$

75. Piri Reis map, 17th century, Berlin Königliche Bibliothek; the note in the view writes in Ottoman "leaded magazine".

76. Oberhummer (1902), Mango and Yerasimos (2001) The view of Lorichs is significant to date Sinan's intervention in the Magazine; then, surely it had been restored in the time of Suleiman the Magnificent (r. 1520-1566).

77. Another view from the early Ottoman period is the versions of Vavassore map, which is not very useful for our case.

78. For the hipped roofed lead covered hans, see; Godfrey Goodwin (1997, 293-302). For the Lead Covered Han in Üsküdar, see; Abdullah Kuran (1987, 55-8).

79. It is very significant that in Piri Reis map both buildings are depicted in very similar lines. Unkapanı was probably restored after the 1561 fire, Erkal (2001). of the gunpowder magazine" fell on the grand vizier Mesih Pasha, who died at the very spot (Koçu, 1951, v. 11, 5952)(69). It is not clear whether the function of gunpowder storage was retained for some period after the explosion or not, but by the mid 16th century the building was transformed into a granary by the construction of a lead covered hipped roof over the bastion (Figure 11)(70). The edifice, which had one of the largest hipped roofs in the Ottoman İstanbul, was called the Leaded Magazine. This place was reserved for the storage of good quality wheat as one of the magazines used by the Gendüm Emaneti, the state office of abundance, until the late 17th century (Evliya Çelebi, 2003, 548).

In fact, as noted in the manuscripts written by Mustafa Sai in an autobiographical format, it was Architect Sinan who restored the arsenal to a grain magazine (71). In almost all versions of the manuscript, there is a building noted as "the Magazine in the Galata Corner" (Crane, Akın, 2006)(72). In a specific version of the Autobiographies, referring to the magazine at the Galata corner, it is noted that Sinan built the "the Leaded Magazine in Tophane". There can be two explanations for the double reference in Sinan's autobiographies: either the same building is noted with two different names; or/and, Sinan worked on the Magazine in the Galata corner in two different occasions and during the last, it was named as the Leaded Magazine (73). In any case, what Sinan supervised for the Magazine is depicted in 16th and 17th century views of İstanbul. In the panoramic view of Galata from the 1590s, the roof is represented over the battlements of the fortifications within a defined projected area (Figure 11b)(74). In the corner of the Magazine a high round tower is shown, probably the former tower of Holy Cross that is depicted considerably higher than the roof of the building, where an additional round part is recessed on top with a pinnacle. In the so called Piri Reis map found in the 17th century versions of Kitab- $\iota$ Bahriye, the same edifice is shown in an axonometric perspective: the leaded roof with a single pitch sits on a rectangular volume inserted within the fortifications of Galata; a round tower with a pinnacle is on the corner facing the Bosphorus (Figure 11c) (75). With the information of these two views, one can also comprehend the round tower and large hipped roof building in the first folio of the panoramic view of Melchior Lorichs, representing the İstanbul of 1559 (Figure 11a)(76). In all of these sources (77), the roof is depicted as inclined from the short side to form a high triangle, and then this line is extended as the top of the roof in the longer direction. Another important feature abstracted in different styles in these views are the roof windows with their own small capping. These windows could have been used for ventilation of the storage as well as lighting; in addition small windows are depicted on the walls.

High and large hipped roofs with wooden structure and lead covering were used in the Ottoman architecture extensively from kiosks to the roof of fortification towers. There is a specific Ottoman building typology from the 16th century where halls with hipped roofs are covered with lead and carried in the interior by wooden columns; this is mostly used in caravanserais and hans like the Büyükçekmece Lead Covered Han and the Kurşunlu Han within the Mihrimah religious complex in Üsküdar (both by Master Sinan)(78). Maybe the closest parallel in form and function to the Leaded Magazine can be the weighing and distribution centre of grain in İstanbul, the Unkapant. The building, which was restored by Master Sinan after a fire, had a hipped roof with a lead cover and roof windows, almost identical to the roof of the Kurşunlu Mahzen (79). In fact, Unkapanı was also 
80. As the hans and magazines of Architect Sinan noted above are mostly not standing or altered, a later example from Edirne can be given for comparison of the hipped roof's interior structure, which is the Aysekadin Han that was constructed in the time of Mehmed III; here, there are wooden columns in the middle carrying the triangular the roof beams.

81. For the grain provisioning of Istanbul in the period when the Leaded Magazine was a granary, see, Demirtaş (2008); for a later period, see Aynural (2005); for the bread shops around the Leaded Magazine see the Court Registers, see, T. Kuran (2010).

82. For kapan see Erkal (2009) we are currently working on a publication concerning the kapans of Istanbul.

83. The provisioning systems of Istanbul and Venice were different and the state granaries occupied a larger space for a smaller populace in the Serenissima.

84. For comparison and the use of battlements on the façade of the grain markets of London, see, Morrison (2003); for Venice, Howard (2000). 85. This may also be related to the increasing Muslim connotation of the Leaded Magazine, which will be opended further in the next part.

85. This may also be related to the increasing Muslim connotation of the Leaded Magazine, which will be opended further in the next part. called as the Kurşunlu Kapan, that is, literally, "the leaded weighing centre" (Kömürcüyan, 1951). In summary, by the 16th century the Ottomans constructed several large hipped roofs covered with lead over large halls, which all took the adjective "leaded" respectively (80). In the absence of concrete evidence, we may only guess that the granary of the Leaded Magazine could have been formed of several wooden floors carried by wooden columns over the masonry substructure. The inside of the hipped roof could have been a space of storage by itself. If we remember that the blueprint of the Magazine is over $35 \mathrm{~m}$. in the short and $50 \mathrm{~m}$. in the long side, then, the area covered by the hipped leaded roof was one of the largest of its kind in the city.

Grain was imported to İstanbul mainly by sea, and logistically the waterfront was an ideal site for a granary. However, the problem of humidity by the seashore was a fact, where the undercroft of the Leaded Magazine probably provided a perfect insulating space. Over the undercroft, within the wooden stories beneath the hipped roof was the storage area for the grains of the city. Evliya Çelebi $(2003,548)$ states that "wheat with large grains (that actually is referred as 'camel teeth') are imported from the provinces [...], which are stored in this granary, are distributed daily as livelihood in accordance with the records" (81). In this sense the granary was an official weighing and distribution center -a kapan or an emanet (82).

The former Fort restored into a granary in the Leaded Magazine was not very different in grandeur, location and expression, than the purpose built state granaries of Venice, which as one of the largest granaries of the premodern era, occupied a very distinctive site on the shore of Piazza San Marco (Howard, 2000)(83). As it is almost generic for the storage building of this period, the granaries of Venice had battlements on the top of the opaque façades with very small openings (84). In İstanbul, as the former Fort was converted to a granary, the battlements were, naturally, more authentic than simply a symbolic feature. The leaded magazine was not a fort-like granary (like many medieval magazines) but a fort made into a magazine, which logistically, climatically and symbolically fulfilled its function. The choice of "the corner of Galata" for a major granary of İstanbul was not politically very different from Venice's site selection; anyone entering the Golden Horn would have seen the abundance of essential items and how they were jealously controlled by the State. In the Ottoman period what had to be enchained in the Golden Horn, as the main trade harbor, was the economic flows into the capital city and the Leaded Magazine converted from the Fort of Galata was an artifice of this transformation.

\section{THE CUSTOMHOUSE}

The leaded roof that gave its name to the Magazine was intact for more than a century; the granary was converted to the main storehouse of the Galata maritime customs in 1676. However, before getting into the details of this transformation it is important to note the changes in the close vicinity. The church of Santa Clara/ San Antonio/ San Nicola adjacent to the eastern side of Magazine (on the left entering from the Gate of Leaded Magazine) was closed to worship in 1606 (85). By the 1640s the grand vizier Kemankeş Mustafa Pasha had his mosque built in the place of the former church, as an elevated prayer hall over shops with a single dome and a minaret (as depicted on the Piri Reis map); the edifice can be a sign 
86. Around 1643, a fire broke from the ships on the quay of Galata and on the occasion the face of grand vizier Kemankeş Mustafa Pasha had burnt. It should not be a coincidence that in the two years after the fire Ekrem Koçu gives the date of the fire as 1635 in reference to the Chronicle of Naima; (vol 11/5953) in Kömürcüyan, the date is 1641-42; (K 1641-42); see also Ayvansarayi (429).

87. Yağkapanı Gate was in the middle of the Galata waterfront, marked by the Ibrahim Paşa mosque.

88. The grand vizier had shops, and hans constructed from the Karaköy Gate to the Kurşunlu Mahzen, which he endowed to the Holy city of Medine, Andreasyan, $(1973,79)$.

89. Ekrem Koçu states that the fire broke because of the munitions of the navy was located in the Magazine; the locked building burnt for fifteen days and when the doors of the magazine were opened, the fire accelerated and the whole merchandise were burnt (vol 11/5963)

90. The Ottoman government temporarily confiscated four Venetian ships for its use, then, the cargo of these ships were transferred to the Leaded Magazine. When the ships were returned to their owners, the custom officers demanded extra tax from them. In the ambush, the magazine took fire and burnt with the goods of the merchants.

91. Jean Baptist Liebaux's copy of Grelot map from 1705 map includes the mosque (Yetişkin Kubilay 2009, 73-5).

92. A document in the Ottoman Archives mentions the construction of a kameriye a pergola on the way leading to the Kiosk by the Head Officer of the Customhouse Ebubekir Ağa (BOA 27/2836 İE.SM); this may rather denote the çardak, the office of the customhouse.

93. The word qasr, from Arabic epistemologically is linked to the early Islamic castle / forts with a quadrateral plan. In Kursunlu Mahzen, the Sultan's Qasr juxtaposed with the qasr in time and space.

94. The conversion of the Kiosk to the customhouse office is given as 1822 in Hadikat, however several documents in the Ottoman archives point to a later date. An imperial edict from 1826-27 talks on an intervention for the opening of the passage to the Kasr- 1 Hümayun "Tuna ve Eflak tarafindan yă ve erzak getiren kayıkların Kurşunlu Mahzen'in önüne yanaşması oradaki Kasr-1 Hümayun'un nezaretine mani olarak men edildiğinden, Kasr'ın duvarından Yeni Mizanönü'ne kadar on iki arşınlık yere bir iskele yapılması hakkında" (BOA, 276/16203/HAT).

95. The Kiosk later has been a major inspiration for Eldem's celebrated work, the Taşlık Coffeehouse.

96. View of Dessonville is in National Library Paris; Melling (Long Stories, 2008); Meyer (Eldem, 1974); Lewis (1936); Barker (originally 1800, published in 1813). of gratitude as the Vizier had faced death at the spot but can also be an example of muslim sacralization at a major non-muslim neighbourhood (86). In 1676, when the Galata customs around the Yağkapanı Gate was burnt down (87); the grand Vizier Merzifonlu Kara Mustafa Pasha decided to transfer the customhouse from Yağkapanı to the Leaded Magazine (88). The granary and its waterfront were transformed into the depot and the quay of the Galata Customs; the area was thereafter also called as the Galata Customhouse.

The Galata customs stayed under the roof that Architect Sinan built for a very short time, since in 1683 a great fire occurred in the Magazine severely damaging the edifice (89). In the 17th century manuscripts of Eremya Çelebi Kömürcüyan on Austria and Ottoman relations, the fire in the Magazine is related with the events around the Venetian maritime blockade after the Second Vienna Siege and its confrontations in İstanbul (90). In an ambush between the custom officers and Venetian traders, a fire broke out, when "the roof of the Magazine blew up and its four walls were left bare" (Andreasyan, 1973, 79). It can be said that after this calamity, the Magazine, which was roofed for a hundred years, returned back to the Arsenal depicted in the Buondelmonti maps.

When Tournefort $(1705,36)$ had seen the waterfront of Galata in 1700, where, in his words, houses filled the front of the fortifications till the Customhouse including the round tower, he should have also witnessed the bare walls of the Magazine that no longer had a leaded roof but was still called as the Leaded Magazine (91). The Customhouse had two gates; one was on the quay wall, the other was opening to the back street; as shown in some 19th century maps there was a passage within the Magazine forming literally a gate-house. The walls of the customs functioned as an open-air enclosure with provisional shelters and barracks without any visible expression on the outside.

Nevertheless, a very significant structure was built at the southwest corner of the Magazine in 1716, that is a kiosk presented to Sultan Ahmed III by his grand vizier Şehid Ali Paşa: the Leaded Magazine Kiosk (Ayvansarayi, 2001, 433-5; Eldem, 1974; Tanman, 1993)(92), The Sultan Kiosk, also known as Kasr-ı Hümayun meaning an imperial pavilion (93), was restored in 1822 following the damage of the 1819 fire; then, it was converted to the office of the Port authority (94). After several alterations the building was finally demolished after a fire around 1870. The Leaded Magazine Kiosk is one of the most celebrated Kasr-1 Hümayun's of İstanbul, which was surveyed and restituted according to original sources by the famous architect Sedat Hakkı Eldem (1974)(95). Different episodes of the Kiosk's architecture can be observed in the views of Dessonville, A.I. Melling, H. Meyer, F. Coke Smyth, panorama of H. A. Barker and different photographs from 1850s and 60s (Figure 12-14)(96). In all these depictions, it is very clear that the edifice partially sits on the walls of the Magazine while the rest is carried over columns or by big projections. The Kiosk, as well as the custom warehouses, was reached from an arched entrance on the wall facing the quay that was specifically roofed by a canopy (most probably coinciding with the present staircase to the Offices from the front street); from the entrance an enclosed ramp/staircase led up to the Kiosk. Having a cross plan with a central sofa, the front room of the Kiosk was projected expansively towards the quay on beams bearing on the Magazine wall, which was covered over to form a single console. As can be witnessed in the H.A. Barker panorama, the roof of the Kiosk had large eaves and was 
97. The Gate of the Magazine is at the 2nd bay of the building from the west, there is hardly any place for the Kiosk left. Eldem places the fortification wall beneath the building at this point, which, however, was combining the magazine at its center in Coke-Smyth's view, the Kiosk is shown as aligning the southwest façade.

98. There are two imperial edicts from 178788 noting the navy ceremony (BOA, 22/1049/ HAT); 26/1261/HAT; another edict with the same purpose, is from 1804-05 (BOA, $114 / 4568$ HAT)
Figure 12. Detail from the view of Dessonville, Vue de Pera, Galata et d'une partie de Constantinople 1721, copied from the original in Biblioteque Nationale Paris, Cartes et plans, GE SH 18E PF 98BIS DIV 7 P 4 . covered by lead; after the fire of 1819, the lead cover was removed and replaced by tiles. In the restitution of the Kiosk the major difficulty is the section by the southwest wall; as Eldem interpreted soundly, the placement of the gate of the Magazine as well as the views from the Galata Tower suggest that the arm of the cross plan of the Kiosk on the southwest side should make another projection over the wall as the one on the front façade (97).

Across the Golden Horn, by the major customhouse of İstanbul known as Eminönü, is located one of the most significant Sultan kiosks of İstanbul; the building was constructed as a resting place for the Sultan interconnected to the special prayer room within the New Mosque in the 17th century. Furthermore, the Kiosk formed a point of surveillance for the harbor and the customs (Thys-Şenocak, 2006) as an omnipresent emblem of the Sultan's rule. The Sultans Kiosk in the Leaded Magazine is a twin of this Eminönü Kiosk. In the photographs taken from the Serasker tower by the 1850s (Konstantiniyye'den İstanbul'a, 2006), it can be seen that while the front façade of the Leaded Magazine Kiosk was oriented to the Galata customs, the southwest façade on the other side of the walls faced directly the Golden Horn and the İstanbul customs. By the early $18^{\text {th }}$ century, near being places of pleasure over the quotidian life, the Sultans Kiosks had formed a visual surveillance axis and a bridge of gaze between the two heads of the maritime customs. Moreover, as openly stated in several documents in the Ottoman archives for the Abdülhamid I and Selim III periods, the Kasr-ı Hümayun was also used for the imperial ceremonies during the arrival and departure of the navy (98). As noted above the Yalı Kiosk and the Sepetçiler Kiosk had this ceremonial function by the Topkap1 Palace waterfront; significantly, these are among the possible points where the chain of the Golden Horn was attached in the past.

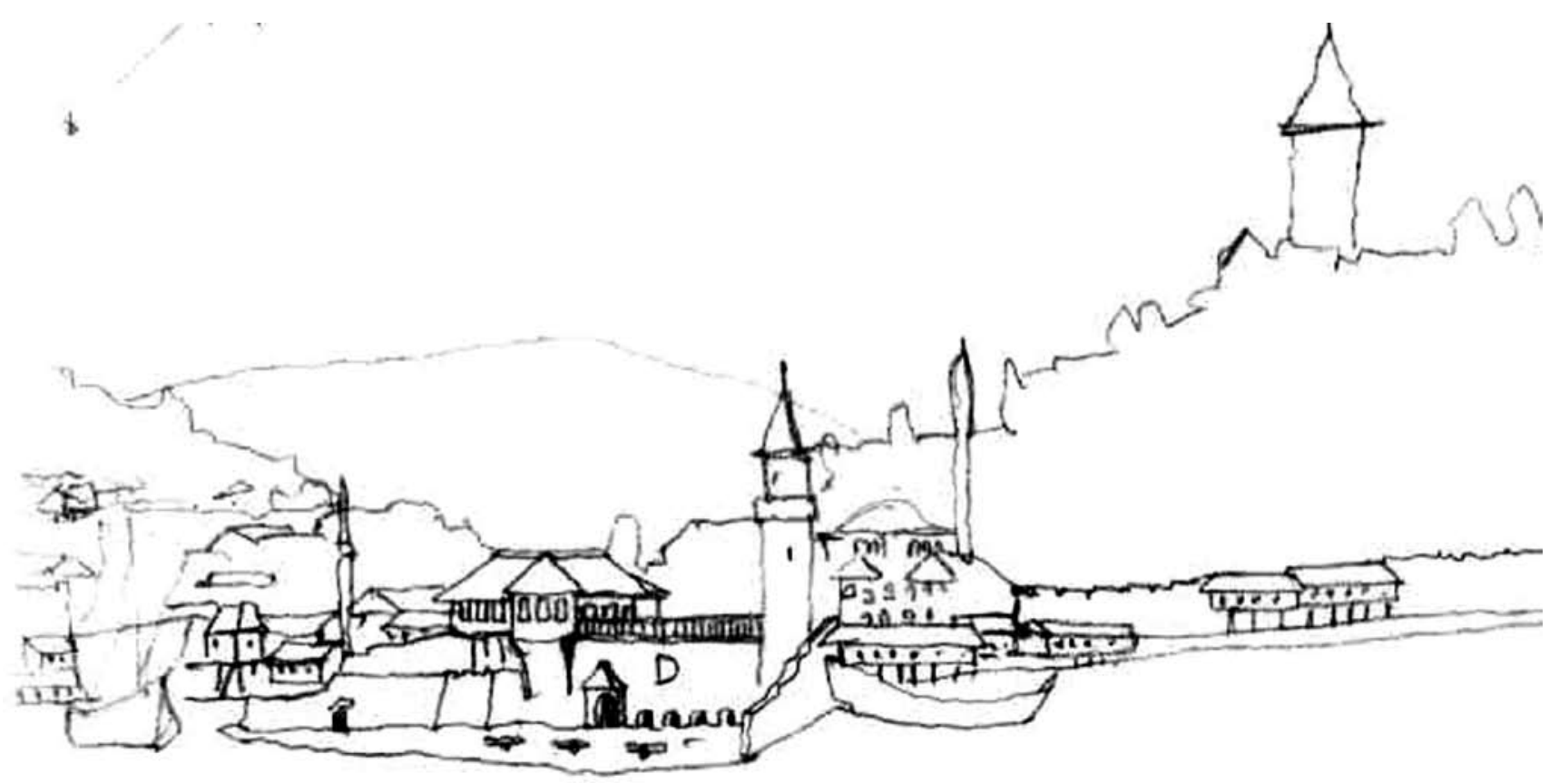


99. Other striking elements are the two perpendicular walls closing off the shore; these were called as "brachilion" in the Byzantine period.

100. "One of the granaries is the Leaded Magazine with a minaret in Galata that was executed by Ömer, son of Abdülaziz. (Sultan) Murad Han willed to make it a mosque, but unfortunately that was not granted to him" $(2003,548)$.

101. The so called Arab Mosque in central Genoese Galata was converted from the San Paolo church with the proposition that this building was originally founded during the Umayyad sieges when "Galata" was taken and inhabited by the besiegers. Arab Cami is also significant in terms of the publics consiousness of architectural forms and styles, as here the former bell tower was interpreted stylistically as an Umayyad minaret.

102. There is no contemporary document on the sieges of Constantinople written in Arabic; the chronicles concerning the Umayyad attacks are earliest from the 11th century. In fact, although the events and the persons concerning the three sieges (668-69, by Yezid and Ayyub el-Ensari in the time of Mu'a-wiya; 672-679 for seven years excursions from the sea base Arteka in the Marmara Sea in the time of Mu'a-wiya; 716717 by Maslama in the reign of Caliphs Omar and Suleiman) could have been merged, they show a general coherence with the Byzantine chronicles (el Cheikh, 2004, 60-4).

103. The imperial praetorium, that is a municipal function was located at the Forum of Leo in the first hill of Constantinople in the time of the siege; however, in the time of emperor Constantine VII, who gives the specific information, it was at the Gate of Drungarios in close proximity to the mosque of the muslim traders known as Mitaton. Ağır $(2009,81)$ locates Mitaton near Bahçekapı, along St. Irene Church, and adds that there may be another mosque than Mitaton in Constantinople.

\section{THE MOSQUE}

One of the most significant depictions of the Leaded Magazine after the construction of the Imperial Kiosk is the view of Dessonville dating 1721 (Figure 12). Here the five gates of the undercroft, the arched gate to the custom magazine and the kiosk, as well as the round tower at the corner are shown in their totality; furthermore, the battlements of the walls of the Magazine are still visible (99). Such an architectural ensemble convoluted with multiple forms and meanings could have generated multiple perceptions on the Leaded Magazine. At least from the 16th century on, there were ones who saw the round tower as the minaret of the first mosque in İstanbul and the undercroft oriented to southeast qibla direction as its first prayer hall. Belief and historical consciousness would thus have connected the Magazine back to its original foundation period.

Evliya Çelebi noted the attempts of Sultan Murad IV (r. 1623-1640) to convert the magazine in Galata that was, in his words, constructed by an Umayyad caliph "with a minaret" (100). Immediately after the taking of the city by the Ottomans, the reappraisal of the sites related with the Umayyad sieges had been a means of territorialization of the Muslim sacred space within the new capital; the discovery of the relic of Ayyub el-Ensari and its adoration with a tomb is the most definite example (Kafesçioğlu, 2009, 45-52; Özaslan, 1999, 379-99). Likely, Galata is a place that was religiously territorialized by the sacralization of some locations in reference to the Islamic histories; the Arab Mosque in Galata is a major case (101). The Leaded Magazine is another site the Muslim past of which was "discovered" with reference to the Umayyad excursions through the myths, texts and finally the site. In relation to this long process of discovery that took nearly 300 years, it is relevant to ask how the idea of the Magazine/Fort originally being a mosque had evolved from. Answers to this question are important both literally and architecturally. As already noted, in order to better understand the background of the foundation myths one should go back to the Arabic and Byzantine sources concerning the Umayyad sieges (102). One of the major points that the sources agree on the Third Umayyad siege is that the siege was removed by the concession to construct a mosque in the Byzantine capital. A credible source is the chronicle of emperor Constantine VII Porphryrogenitus (r. 913-959), where may be the clue of the relation of the mosque with the Fort: "...Maslama, who made an expedition against Constantinople and at whose request was built the mosque of the Saracens in the imperial praetorium." (Moravesik and Jenkins, 1967, 93) the mosque of Constantinople has been alternatively located by the Byzantinists near possible sites for the imperial praetorium that is specified as the residence of the city's governor, and in any case this was neither in Galata nor near the Fort (103). Nevertheless, praetorium also means the emperors headquarters during a combat; this meaning of the term, maybe in translations, could have related the site of the mosque in the written sources and myths to the Fort of Galata by stating the fact that the area around the castle could have been a combat zone during the siege -emperor Leo III's opening of the chain, maybe the strongest link in this weak connection.

In the reign of Mahmud I (r. 1730-1754), it was by the prophecy of a Nakshibendi sheikh from Damascus that the relics of three martyrs from the siege were discovered by the wall of the Magazine in leaded coffins, to further elevate the Islamic connotation of the site -and bring a new reading on the term "leaded". It was said that the relics were found buried 
104. The minaret of the Kemankeş mosque was also damaged.

105. The relics are said to be of Vehb bin Huseyre (inside the rails, who joined the second Umayyad siege); Amr bin As who is the conqurer of Egypt and who was dead at the time of Umayyad sieges but is believed to visit his tomb within the mosque; Süfyan bin Uyeyne, resting in the Tomb was born in the 8 th century and died in 814 . The tomb has been constructed and restored several times,
Figure 13.1. Leaded Magazine as the customhouse of Galata and the Leaded Magazine Kiosk by H. Meyer, 1824 (Eldem, 1974)
Figure 13.2. Leaded Magazine as the customhouse of Galata and the Leaded Magazine Kiosk by F. Coke-Smyth (engraved by Lewis), 1836 (Gravürlerde İstanbul, ...). on the side of a wall in a chamber the gate of which was "leaded" by the Umayyads during the siege (Ayvansarayi, 2001, 433). As the relics were carried inside the undercroft, the space was adorned and converted into a mosque by the Grand Vizier Mustafa Pasha with the permission of the Sultan in 1752. The former round tower was turned into a minaret, which, however, was totally demolished in the 1766 earthquake (Pamukciyan, 1994, 34)(104); a new minaret was constructed over the wall on the same corner of the Magazine. The description in Hadikat'ül Cevami (The Garden of Mosques) revised in the early 19th century represents conditions almost identical to the present day: The mosque had four gates; two of them faced the seaside, the other two opened to "the land" with thirteen steps; there were forty two identical piers inside the Prayer Hall; there was a fountain on the front wall and ablution fountains in the forecourt. There were three coffins within the mosque, one of them being a separate tomb and two others within the Hall behind the rails (105). The conversion was marked by the mihrab placed on the front wall by the quay (Figure 5).
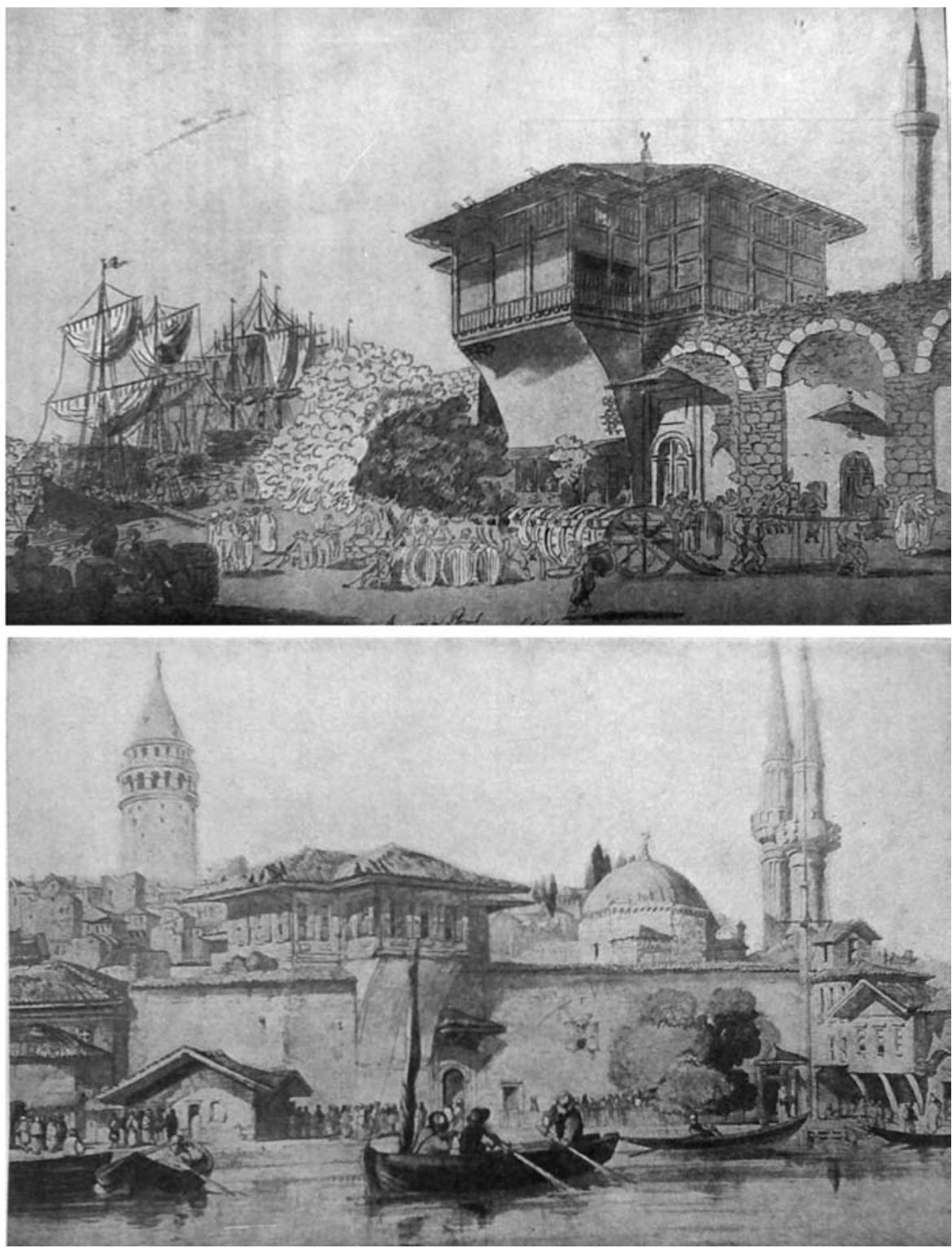
106. Among many views, a sketch of Antoine Ignace Melling from the Suna-İnan Kıraç collection, is the one that briefly depicts the Galata corner, almost duplicating the view of Dessonville after a century (Long Stories, 2008, 70-1).

107. Apart from the views, the maps generally point to the Galata customhouse as the Kurşunlu Kiosk or Kurşunlu Mahzen, such as the Kauffer map; a Spanish map from 1783 by Tomas Lopez notes "the ruin of the fort where the chain that closed the Port was stretched" (Yetişkin Kubilay, 2009, 114-9).

108. H. Meyer can be the portrait painter and engraver Henry Hoppner Meyer (1782-1847); as far as this research is concerned Meyer's travel to İstanbul could not have been traced. However, as in the case of Coke Symth and Lewis; H. Meyer can be the engraver of the view as well.

109. For the 18 th century there are many documents in the Ottoman Archives for the placement and restoration of cannons.

110. That is known with the name of the engraver John Frederick Lewis (1805-76); here cited after the sketch book in Victoria and Albert Museum, Searight Middle Eastern Images Collection.
The conversion from the magazine to a prayer hall cannot have been solely due to the holy presence of the martyrs but also to the ongoing myth of the earlier mosque within the Leaded Magazine, where the architectural peculiarities of the site -that is the undercroft- should have been essential in the reappraisal: The hypostyle order of the piers and groin vaults is analogical, in very abstract terms, to the early Islamic mosque typology proper. In other words, the legitimacy of the mosque beneath the Magazine could have been supplemented by an architectural analogy. The conversion had also been literary; the meaning of the Leaded Magazine from the former hipped leaded roof had been translated to the leaded coffins of the chambers of the martyrs eighty years after the demolition of the roof.

\section{THE WATERFRONT}

As the Leaded Magazine mosque was opened to prayer, the enclosure above the undercroft continued to function as the Galata customs and thus the waterfront was the customs' quay. In 1800, Sarkis Hovhannesyan wrote that the magazine was formed of several layers, which must have been within the upper enclosure. The Magazine, the Sultans Kiosk, the Kemankeş Mosque and their minarets form an ensemble on "the Galata corner" that is shown in most of the representations done from the entrance of the Golden Horn by the Westerners (106).

In the early 19th century, it also became possible to find depictions directly focusing on the waterfront façade of the Kurşunlu Mahzen and the customhouse quay; these views are significant not only for their time but also for the archaeology of the Magazine (107). For example, in H. Meyer's view 1824 (108), published by Sedat Hakkı Eldem (1974, Figure 159) where the Magazine is in fact partially visible and the main focus is the recently restored Sultan's Kiosk; two gates are depicted, one belonging to the Kiosk and the Magazine, the other being one of the gates of the mosque (Figure 13.1). However an interesting detail can still be noticed; the cannons are still placed on the Quay within the imported items in wooden barrels and packs (109). Further, strikingly enough, the wall is depicted as formed of high stone piers and arches, which are filled by stones in between and above; the top of the wall is uneven and there is no trace of any battlements depicted in the former views. The high arches seem coincide with the bays in the plan of the substructure, however there is no mark of the level of crypt within the arched system. If the architectural information in the view is to be taken for granted, what does it refer to? Are these the remains of the arched walkways for guards as reminiscent of the arched walkways preserved on the outer walls of the Theodosian Land walls, which are seen as relieving arches on the exterior façade? (Müller-Wiener, 2002, 286-322) If these are the arched walkways, then does this point to a change in the façade of the Fort, where they have become exposed to the outside? In 1835-36, John Richard Coke Symth (1808-82) realized another view that may provide evidence on the issue (110), which represents a clear façade with less accentuated traces of the relieving arches; however, these are not related to the modulation of the interior (Figure 13.2). The wall has tile capping all over; that is also seen in the photographs of the later periods. Do the changes in the views of Meyer and Symth point to a restoration? As noted above, the Sultan's Kiosk was damaged in 1819s and restored at the time of Meyer's visit. Coke Smyth does not only depict the Magazine, the Kiosk, the gates, the Kemankeş mosque, and the two minarets but also represents the custom quay with the offices on the ground level and 

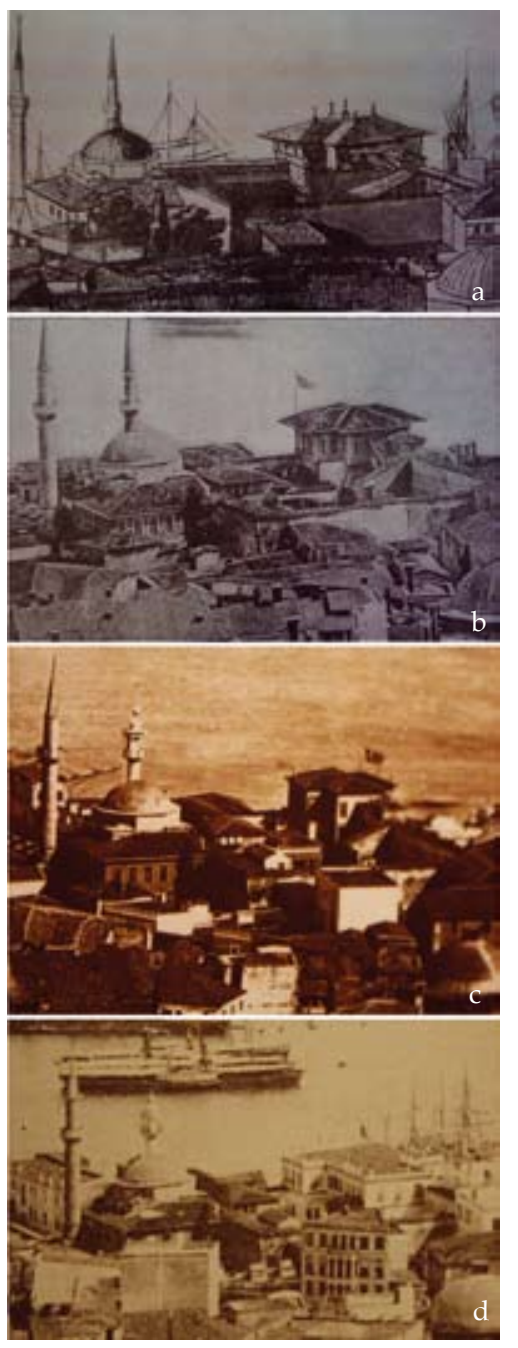

Figure 14. Depictions of the Leaded Magazine from 1800 to 1875 , comparative analysis by the author; a. Detail from the panorama of Henry Aston Barker, 1800, taken by S.H. Eldem (1974); b. Detail from the photograph of J. Robertson, 1854, taken taken by S.H. Eldem (1974); c. Detail from the photograph of 1868 with the Arabic styled minaret (Konstantiniyye'den Istanbul'a , 2006); d. Detail from the photograph of 1875 after the demolition of the front façade of the Leaded Magazine and the construction of the first Public Sanitation Office (Öztuncay, 2004).

111. Subterranean Mosque after Sultan Mustafa I, rather than Kemankeş Mustafa Mosque.

112. The exact date of the sketch is 27 September 1839; it is from the sketchbook of Flandin, now in the Searight collection of Middle Eastern Images in Victoria and Albert Museum, London.

113. A document in the Ottoman Archives from $1839-40$ is on the selling of the Old Customhouse after the construction of the New Customhouse; this should not be the Leaded Magazine (BOA/109/4844/C.ML). the wooden palisades used for the separation of the inspected people and goods. In the 1815 Head Gardener registers the buildings around the Galata customs are listed as: the Leaded Magazine, Imperial Kiosk, Mustafa Mosque (111), port inspectors office, the office of the Galata major (Kayra and Üyepazarc1, 1992).

\section{THE QUARANTINE}

A sketch drawn by Eugene Flandin dating from 1839 frames the Leaded Magazine (112): although the Galata background is totally imaginative and the Kiosk is fanciful, the Leaded Magazine is depicted with the new Galata customs building representing a precedent of the Ottoman state office type in the 19th century (Figure 15.1). In its neo-classical expression, the New Customhouse projects a shadow on the archaic image of the former Magazine (113). In fact, the 1800s is a time of decomposition for the Leaded Magazine within the conditions of the ports' transformation to a modern infrastructure, where not only the building but also its relation with water is radically altered. After the construction of the new customhouse the magazine began to work as the quarantine and the public health administration (114). In addition to the cartographical evidence provided by maps, this process can also be perfectly observed from the photographs taken from the Galata Tower after the 1850s (Figure 14).

Comparing the panorama of H. Barker drawn by 1799-1800 (Erkal, 2008) and the first panoramic photograph by James Robertson (Eldem, 1974) from the Galata Tower; it can stated that the Magazine worked as a customhouse within the same architectural lines in the first half of the 19th century; except for the slight changes within the Kiosk as noted above (115). The counterpart of these views in plan can be the d'Ostasya map of 1858-60 (116), where the frame of the Magazine as well as the quay can be observed; maybe the most important data in the map are the two closed shelters placed within the frame of the Magazine from the entrance to the back street.

Wolfgang Müller-Wiener $(1998,57)$ states that the Magazine was severely damaged after a fire in 1863. The panoramas of 1868 frame a similar view with the 1850s (Eldem, 1974; Tanman, 1994): the Kiosk had been restored with shorter eaves and projections; furthermore a dome has been built over the tomb adjacent to the Mosque (Figure 14c)(117). A significant change is the minaret of the Leaded Magazine, which is styled after Egyptian minarets that have an open prayer balcony that is roofed by a miniature dome/sphere instead of the classical Ottoman pinnacle; the Egyptian style minaret is a significant example of the symbolic relation with the past -the Umayyad sieges. Meanwhile, the urban fabric adjacent to the building has become denser and higher making the Magazine less visible.

A major change in the 1860s was the demolition of the Galata fortifications; subsequently, the Magazine was also freed of its fortification context (118). Probably with this transformation, a major project was carried on the Magazine after another fire: the southeast and southwest walls were demolished to open a place and a platform for the offices of the littoral public health related with the port authority in 1871 (119). The office was a two-storied wooden construction building on a sub-basement (over the Mosque); pictured in the photographs of 1875 (Öztuncay, 2003, 701). The office of the 1871 was demolished by a fire and was rebuilt in 1877 (120); the inscription panel in the Tomb dates to 1878 as well. The photographs 
Figure 15.1. Detail from the sketch of Flandin, 1839, The Leaded Magazine with the New Customhouse of Galata, original in Victoria and Albert Museum, Searight Collection of Middle Eastern Images.

Figure 15.2. The photograph of the customhouse quay after the demolition of the front façade of the Leaded Magazine and the construction of the Public Health Offices, ca.1870-90.

114. Müller-Wiener $(1998,136)$ states that the building -probably the Kiosk- functioned for the inspection of the passport papers until 1840 in reference to S. Kuneralp's paper on Emin Muhlis Pasha's work in Foreign Affairs Ministry. The littoral quarantine office was founded in 1830s, as the Leaded Magazine functioned as the office after the mid 19th century; the anchorages on the open shore were used for the quarantined ships.

115. The frame of the Magazine's open enclosure topped by tiles is perfectly visible; the angle differentiation in the northeast corner is legible; the Sultans Kiosk converted to the office of the port authority is now roofed by tiles; the closed ramp leading to the Kiosk is seen above jerry structures within the enclosure; the minaret of the Leaded Magazine mosque in classical Ottoman style can be seen behind the dome and the minaret of Kemankeş Mosque.

116. Here referred after the copy in the İBB Atatürk Kitaplığı no 5692.

117. A document in Ottoman Archives from 1867-68 mentions the restoration of the Ebu Sufyan Tomb (BOA, 883/51/MVL). This seems to be damaged by a fire before 1877 .
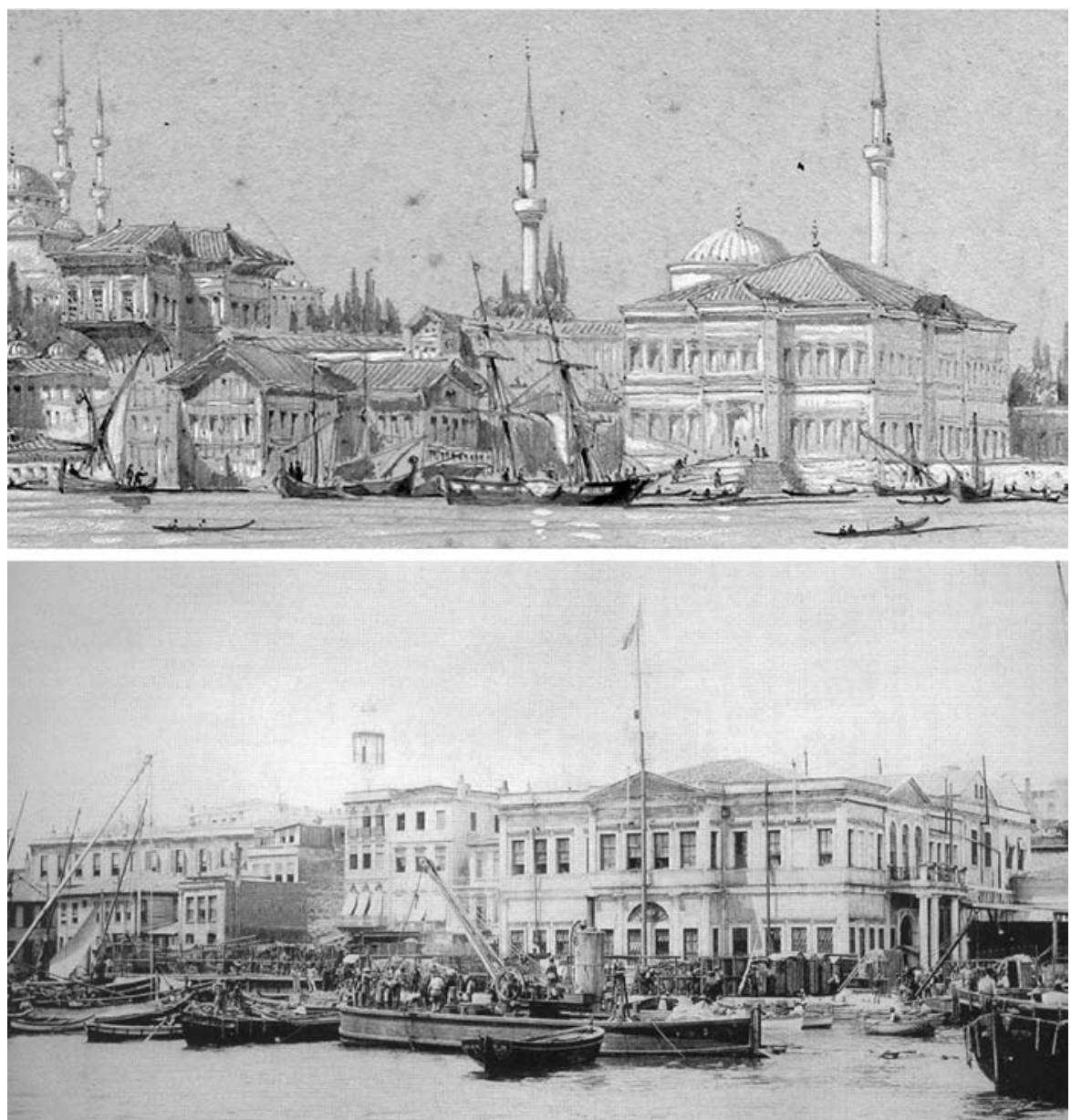

after the 1890's (Atasoy, 2007, 323) depict another stage of the office building. There are documents in the Ottoman Archives on the damage caused by the 1894 earthquake and the consequent rebuilding of the Sihhiye offices (121). Although it is not possible to define the exact time of intervention, the offices on the terrace of the Leaded Magazine were reached by an open stairway (that is probably at the same place with the access of the former Magazine); the building was constructed partially out of the limits of the undercroft on the west. The mosque was restored between 1908-1910 (122); the present-day front of the Mosque, which is stylistically "first national", may belong to this transformation.

As the maps of the period indicate, the erasure of the fortifications did not immediately change the relation with the waterfront. Rather, such a change happened after the construction of the Galata quays, which was realized between 1893-1895 (Erkal, 2010b). The infill for the quays removed the building to the second row within new building plots related with the port. As seen in the postcards of the period, the Quarantine office above the substructure still dominated the waterfront view behind single storied buildings on the forefront (Figure 16). However, as the port was moved to the East, the plots on the waterfront were built over as offices; then the Magazine lost its former relation with the port. It should also be noted that 

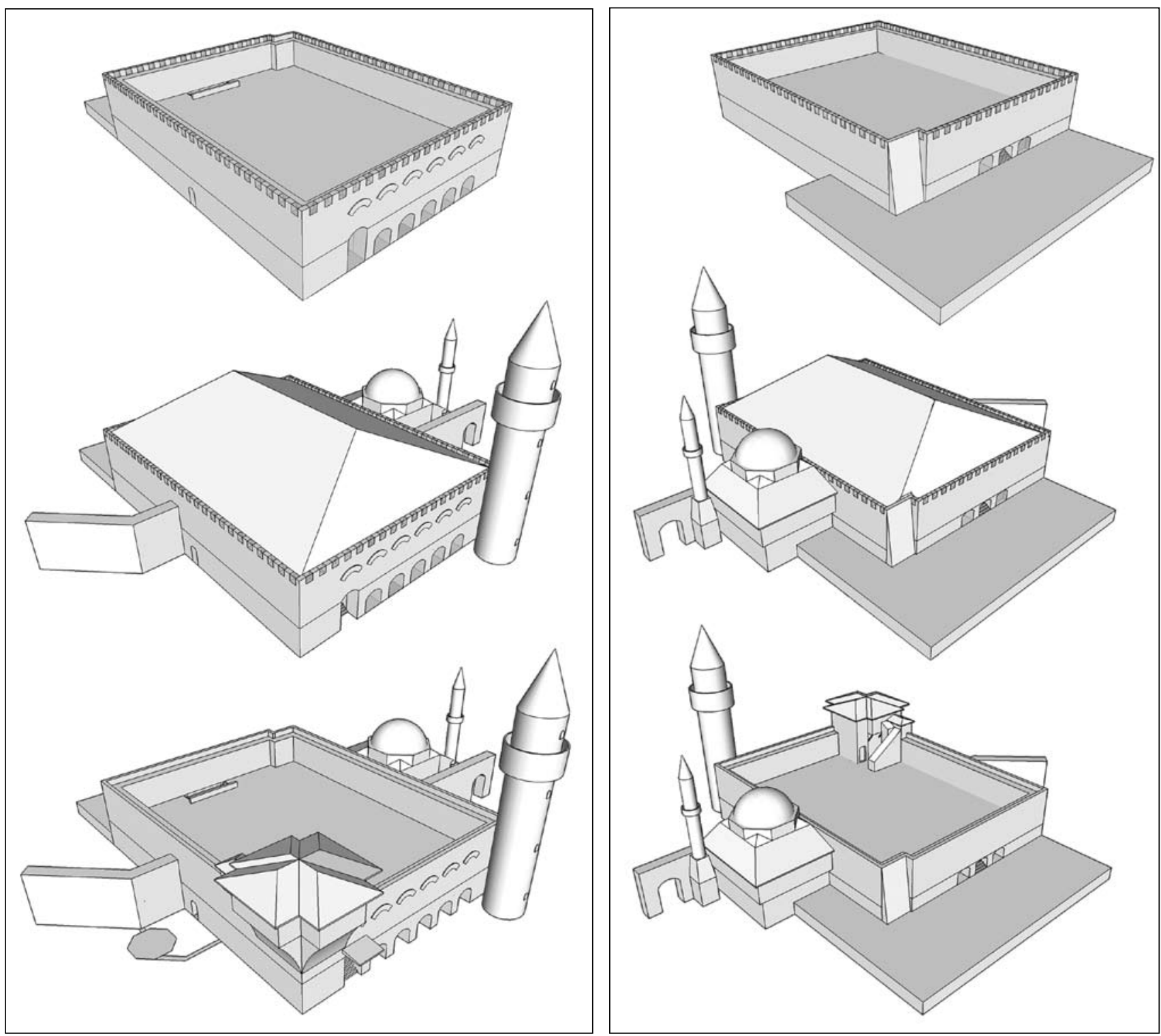

Figure 16. Hypothetical reconstruction of the three stages of the Leaded Magazine: the Fort-Arsenal; the Granary; the Customhouse of Galata, axonometric view from southwest rendering by Özgün Özçakır.

Figure 17. Hypothetical reconstruction of the three stages of the Leaded Magazine: the Fort-Arsenal; the Granary; the Customhouse of Galata, axonometric view from northeast, rendering by Özgün Özçakır. in the process, the building of the chain of the Golden Horn has been set back $50 \mathrm{~m}$. from the sea.

\section{CONCLUSION}

“Kurşunlu Mahzen Câmii'nin imâmı Abdurrahman Efendi'nin nakli: "yatsu namâzına gidince Frenk'in biri hilâllere [aralıklara] gizlenmiş, câminin fergân[d]ını [kokusunu] cukarub sabâhleyin kapu açılur iken Frenk'i tutduk." (123)

The late 1800s defines the architecture of the Leaded Magazine until the contemporary period: the Mosque; the Office building and the remaining walls are within the same lines for the last 125 years (124). As an urban archaeological riddle within the hub of the city, the site of the Leaded Magazine is a cornerstone of the history of the Golden Horn and Galata. Almost all the functions of the historical edifice reviewed here had been related with the spatiality of the urban littoral frontier: defence, provisioning, surveillance, quarantine and sacralization. Whether as a 
118. Zeynep Çelik $(1996,58-9)$ states that the demolition of the walls was issued in 1863 , and the project was finalized by 1865 ; see also, Osman Nuri Ergin. The part of the fortification between the former Gate and the Magazine is still in situ.

119. There are two documents in the Ottoman archives on the construction of Sihhiye offices in 1871 (BOA, 638/44343/I. DH; 23/977/İ.ŞD). The mosque was probably restored within the same undertaking (BOA, 660/ 45938/İ.DH). Philip Anton Dethier in his book of 1873 says that there was a fort by the customhouse, the walls of the Fort still defined the Leaded Magazine that is still used as the quarantine place (76).

120. There is a related document in the Ottoman Archives from 1877 (BOA, 676/13/ ŞD).

121. These specifically point to the inspection of the cracks within the Subterranean Mosque and the terrace (BOA, 305/15/ Y.A.HUS; 450/33676/BEO).

122. There are two documents on this issue (BOA, 154/21/Y.A. RES; 186/51/ŞD).

123. Ekim 1840 'a ait havadis jurnallerinden (Kırlı, 2008, 171).

124. This state of the Leaded Magazine is perfectly illustrated in the municipality cadastral maps of 1914-1918, known as the Alman Mavileri; here, probably according to the strategic importance of the site all the elements from the walls to the light wells are drawn in scientific precision. In the present-day the offices are used by the Hudut ve Sahiller Sağlık Genel Müdürlüğu (Border and Coasts Public Health General Administration). definite type or a converted building, the different stages of the Magazine are all important to exemplify these functions as the corner of the Port of a very significant historical imperial city: Constantinopolis / İstanbul.

Reviewing the history of the Leaded Magazine has brought forth the following (Figure 16, 17):

- The Fort of Galata functioned as the tower of the chain enclosing the Golden Horn that was an increasingly military port at the time; it functioned solely for the defensive, not as a control mechanism for an enclosable trade port. The Fort was almost a $38 \mathrm{~m}$ to $50 \mathrm{~m}$ structure, which was founded on an undercroft with an $8 / 10$ bay system originally having 54 or 63 columns.

- If the groin vaulted undercroft of the Fort is from the foundation period (probably late 7th century), then the Leaded Magazine represents one of the very rare examples of an unaltered Fort substructure; the article examined the conditions for this conservation and their interrelation with the mechanism chain of the Golden Horn. Could this undercroft have been utilized as an arsenal for the supplements of the chain: (the links, the logs, the fire-bearing ships, etc). Another question is whether the five gates known from the sources after the 15th century are from an earlier period.

- The archaeology of the front wall of the Fort as depicted in the 19th century sources shows traces of arches and relieving arches, these have been interpreted as possible covered walkways used by the garrison in the tower. There is no trace of the original gate/s of the Fort, or the point where the chain has been suspended. It has been speculated that at least for the 14th century when cannons were used at the five arched openings on the shore the chain was at the corner towards the interior of the Port.

- It is not clear whether the Fort originally had corner towers; on the southeast corner in the Genoese period a very high tower was erected by the $1440 \mathrm{~s}$. The existing tomb is another point where the possibility of a tower can be considered.

- The Magazine was transformed into a granary by a hipped lead plated roof under the supervision of Master Sinan at least before 1559; this should have been one of the greatest inclined roofs of the Ottoman capital. It was burnt in 1683, after the granary had been converted to the Customhouse of Galata. The leaded roof burnt but the name survived also in relation to the relics of martyrs found in the 18 th century.

- The function of the customhouse continued until the middle of the 19th century, the import items were stored within structures adjacent to the walls of the Magazine- the undercroft could have been used as a warehouse until the middle of the 18th century as well. An Imperial Kiosk was built by the early 18th century at the southwest corner of the Magazine walls; this was the counterpart of the Kiosk by the İstanbul customs. The Kiosk survived, with several restorations, up to 1870 . Both the custom warehouses and also the Kiosk were reached by a gate with a staircase on the southwest corner below the Kiosk that is still preserved as the access to the platform of Offices. 
- The undercroft was converted to a Mosque by the mid 18th century; this was literally and architecturally related with the Umayyad sieges. The Tower was thought to be the minaret of a mosque said to be founded by the Arabs and the undercroft was seen as its prayer hall. The present state of the Mosque is related with the construction of the Quarantine offices by the 1870s. Half of the walls were demolished during the construction of the Office building over the undercroft; the existing walls can now only be observed as fragments within the urban fabric.

The contemporary ensemble within the site of the Leaded Magazine presents a continuation with the historical functions of the littoral frontier: the Public Health Offices are related with the Customhouse functions and surveillance; the Mosque is a perfect example of sacralization on the city edge, connecting the foundation period with the present.

\section{BIBLIOGRAPHY}

AGOSTON, G. (2009) Guns for the Sultan: Military Power and the Weapons Industry in the Ottoman Empire, Cambridge University Press, Cambridge UK.

AĞIR, A. (2009) Istanbul'un Eski Venedik Yerleşimi ve Dönüşümü, İstanbul Araştırmaları Merkezi, İstanbul.

AKIN, N. (2002) 19. Yüzyılın İkinci Yarısında Galata ve Pera, Literatür Yayınları, İstanbul.

Alman Mavileri 1913 - 1914, I. Dünya Savaşı Öncesi İstanbul Haritaları, volume 2 (2002), İstanbul Büyükşehir Belediyesi, İstanbul.

ANDREASYAN, H.D. ed. and tr. (1988) Eremya Çelebi Kömürcüyan: İstanbul Tarihi, XVII. Yüzyılda İstanbul, Eren, İstanbul (first publication in 1952).

ANDREASYAN, H.D. (1973) Eremya Çelebi'nin Yangınlar Tarihi, Tarih Dergisi (27) 57-84.

(ARSEVEN) ESAD, C. (1989) Eski Galata ve Binaları, TTOK, Istanbul (original in Ottoman script, publication date 1911).

ATASOY, N., ed. (2007) Photographs from the Yildiz Palace Albums Souvenir of İstanbul, Akkök Yayınları, İstanbul.

AYNURAL, S. (2005) The Millers and Bakers of Istanbul (1750-1840), Crafts and Crfatsmen of the Middle East, eds. S. Faroqhi, R. Deguilhem, Tauris, London;153-194.

Ayvansarayi Hüseyin Efendi, Ali Sati Efendi, Süleyman Besim Efendi: Hadikatü'l-Cevami: İstanbul'un Camileri ve diğer Dini-Sivil Mimari Yapıları, (2001) ed. A.N. Gültekin, İşaret Yayınları, İstanbul.

BARDILL, J. (2004) Brickstamps of Constantinople, Oxford Monographs on Classical Archaeology, 2 vol.

BARKER, H.A (1813) A Series of Eight Views forming a Panorama of the celebrated city of Constantinople and its environs taken from the town of Galata by Henry Aston Barker and exhibited in his great rotunda, Leicester Square, Thomas Palser, London.

BERGER, A. (1994) Kastellion, İstanbul Ansiklopedisi, Tarih Vakfı, İstanbul (4) 485. 
CAMERON, A., HERRIN, J. eds. and tr. (1984) Parasteis Syntomai Chronikai, Leiden.

Charles Edouard Goad'ın İstanbul Sigorta Haritaları (2007) İstanbul Büyükşehir Belediyesi, İstanbul.

EL CHEIKH, N.M. (2004) Byzantium viewed by the Arabs, Harvard University Press, Cambridge, MA.

CLARKE, E. D. (1810) Travels in various Countries of Europe, Asia and Africa. Volume 1, Cadell and Davies, Cambridge UK.

CRANE, H., AKIN, E. (2006) Sinan's Autobiographies:Five Sixteenth-Century Texts, Brill.

ÇELIK, Zeynep (1996) 19. Yüzyılda Osmanlı Başkenti Değişen İstanbul, tr. Serim Deringil, Tarih Vakfı Yayınları, İstanbul (first published in English, 1986).

DANKOFF, R., KAHRAMAN, S.A., DAĞLI, Y., eds. and tr, (2006) Evliya Çelebi Seyahatnamesi, 1. Kitap, YKY, İstanbul.

DEMIRKENT, I., ed. and tr. (2004) Niketas Khoniates'in Historiası (1195-1206) Istanbul'un haçlılar tarafindan zaptı ve yağmalanması, Eren Kitabevi, İstanbul.

DEMİRTAŞ, M. (2008) Osmanlıda Fırıncılı: 17. Yüzyıl, Kitap Yayınevi, İstanbul.

DETHIER, P.A. (1993) Boğaziçi ve İstanbul: 19. Yüzyıl sonu, tr. U. Öztürk, Eren Yayınevi, İstanbul.

ELDEM, S.H. (1974) Köşkler ve Kasırlar, 2. Cilt, İstanbul; 180-7.

ERGİN, O.N. (1994-1997) Mecelle-i Umur-ı Belediyye, 9 cilt, İstanbul Belediyesi (original in Ottoman script, publication dates 1914-1922).

ERKAL, N. (2010a) Water City, Water Life, Expo 2010 Shanghai Catalogue: Turkey, ed. A. Savaş, Miki Press, Ankara; 87-94.

ERKAL, N. (2010b) Bugün Liman Kara Olmuştur: İmparatorluk Cumhuriyet Eşiğinde İstanbul Rıhtımlarının Dönüşümü, Osmanlı Başkentinden Küreselleşen İstanbul'a Mimarlık ve Kent, 1910-2010, ed. İ. Akpınar, Osmanlı Bankası Arşiv Araştırma Merkezi, İstanbul; 31-48.

ERKAL, N (2009) Kapan, İstanbullaşmak: olgular, sorunsallar, metaforlar, eds. P. Derviş, B. Tanju, U. Tanyeli, Garanti Galeri, İstanbul; 160-5.

ERKAL, N. (2001) Haliç Extra-mural Zone: a Spatio-Temporal Framework for Understanding the Architecture of the İstanbul City Frontier, unpublished PhD Dissertation, Middle East Technical University, Ankara.

ERTUĞ, N. (2008) Osmanlı Döneminde İstanbul Hamalları, Timaş, İstanbul.

EYİCE, S. (1994) Yeraltı Cami, Istanbul Ansiklopedisi, Tarih Vakfı, İstanbul (7) 502-3.

FOSS, C. (1996) Survey of Medieval Castles of Anatolia II, Vol. II: Nicomedia, British Institute of Archaeology, Ankara.

FOSS, C., WINFIELD, D. (1986) Byzantine Fortifications: an Introduction, University of South Africa.

GENIM, S. (2004) Kurşunlu Mahzen Köşkü, Geçmişten Günümüze Beyoğlu, Volume 1, İstanbul Büyükşehir Belediyesi; 127-50. 
GILLES, P. (2000) İstanbul Boğazı, tr.E. Özbayoğlu, Eren Yayınevi, İstanbul.

GOODWIN, G. (1997) A History of Ottoman Architecture, Thames and Hudson, London.

GOTTWALD, J. (1907) Die Stadtmauern von Galata, Bosporus (4) 5-72.

GUILLAND, R. (1959) La chaine de la Corne d'Or, Etudes Byzantines, Paris ; 263-97.

HALDON, J., LACEY, A., HEWES, C. (2006) Greek Fire revisited: recent and current research, Byzantine Style, religions and civilization, ed. E. M. Jeffreys, Cambridge.

HASLUCK, F.W. (1918) The Mosques of the Arabs in Constantinople, The Annual of the British School at Athens (22).

HOWARD, D. (2000) Venice and the East: the Impact of the Islamic World on Venetian Architecture 1100-1500, Yale University Press.

HÜR, A. (1994) Cenevizliler, Istanbul Ansiklopedisi (2) 407-40.

In the Daylight: 8000 years of İstanbul Exhibition of Marmaray, Metro, Sultanahmet Excavations (2007) Vehbi Koç Vakfı, İstanbul.

İstanbul ports : cradle of civilizations = Credito di civillizzazione.. (2006) ed. Sercan Özgencil Yıldırım., Istanbul Greater Municipality.

JANIN, R (1964) Constantinople Byzantine: developpement urbain et repertoire topographique, Rodolphe Guilland, Paris.

KAEGI, W. (2003) Heraclius: emperor of Byzantium, Cambridge.

KAFESÇİOĞLU, Ç. (2009) Constantinopolis/ Istanbul: cultural encounter, imperial vision and the construction of the Ottoman capital, the Pennsylvania State University Press: Pennsylvania.

KAHRAMAN, S.A., DAĞLI Y., eds. and tr. (2003) Günümüz Türkçesiyle Evliya Çelebi Seyahatnamesi: İstanbul, Volume 2, YKY, İstanbul.

KAHZDAN, A. (1998) Polis and Kastron: in Theophanes and in some other historical texts, Eupsychia: mélanges offerts à Hélène Ahrweiler, Volume 2, eds. H. Ahrweiler, M. Balard, publications de la Sorbonne, Paris; 349-50.

KAYRA, C., ÜYEPAZARCI, E. (1992) İkinci Mahmut'un İstanbul'u: Bostancıbaşı Sicilleri, İstanbul Belediyesi Yayınları.

KIRLI, C. (2009) Sultan ve Kamuoyu: Osmanlı Modernleşme Sürecinde "Havadis Jurnalleri" 1840-1844, Türkiye İş Bankası, İstanbul.

KOCABAŞ, U., ed. (2008) The Old Ships of the New Gate, Ege Yayınları.

KOÇU, E. (1958-1971) İstanbul Ansiklopedisi, 11 cilt, İstanbul.

Konstantiniyye'den İstanbul'a, XIX yüzyıl ortalarından XX yüzyıla Boğaziçi'nin Rumeli Yakası Fotoğrafları (2006) ed. S. Genim, Pera Müzesi, İstanbul.

KUBAN, D. (1996) Istanbul: an urban history: Byzantion, Constantinopolis, Istanbul, Tarih Vakfı Yayınları, İstanbul.

KURAN, A (1987) Mimar Sinan: the Grand Old Master of Ottoman Architecture, Ada Press, İstanbul.

KURAN, T., ed. and tr. (2010) Social and Economic Life in Seventeenth Century Istanbul: glimpses from Court Registers, Türkiye İş Bankası, İstanbul. 
Long Stories: Istanbul in the Panoramas of Melling and Dunn, (2008) ed. E. Işın, B. Tanman, İstanbul Araştırmaları Enstitüsü, İstanbul.

MADDEN, T. (2006) Food and the Fourth Crusade: a new approach to the "Diversion Question", Logistics of Warfare in the Age of the Crusades, ed. J. H. Pryor, Ashgate; 209-28.

MADDEN, T., QUELLER, D. (2000) The Fourth Crusade: the Conquest of Constantinople 1201-1204, University of Pennnyslvania Press, Philadelphia.

MAGDALINO, P. (2000) The Maritime Neighborhoods of Constantinople: commercial and residential functions, sixth to twelfth centuries, Dumbarton Oaks Papers (52) 209- 26.

MAMBOURY, E. (1953) The tourists' Istanbul, tr. M. Burr, Çituri Biraderler Basımevi, İstanbul.

MAMBOURY, E. (1924) Constantinople: Tourists' guide, Rizzo and Son, Istanbul.

MANGO, C., ed. (2002) The Oxford History of Byzantium, Oxford University Press.

MANGO, C., SCOTT, S.R., eds. and tr. (1997) The Chronicle of Theophanes Confessor: Byzantine and Near Eastern History, AD 284-813, Clarendon Press, Oxford.

MANGO, C. (1993) Studies on Constantinople, Varorium, Surrey, UK.

MANGO, C. ed. and trans (1990) Nikephoros, Patriarch of Constantinople: Short History, Dumbarton Oaks, Washington.

Melchior Lorichs' Panorama of Istanbul - 1559 (2001) ed. C. Mango, S. Yerasimos, Ertuğ and Kocabıyık Publications, Bern.

Van MILLINGEN, A. (1899) Byzantine Constantinople, The Walls of the City and adjoining historical sites, London.

MORAVESIK, G., JENKINS R. (1967) Constantine Poryhyrogenitus, De Administraio, Washington.

MORRISON, K.A. (2003) English Shops and Shopping: an Architectural History, Yale University Press, London.

MÜLLER-WIENER, W. (2002) İstanbul'un Tarihi Topografyası, tr. Ü. Sayın, YKY, Istanbul (first published in German, 1977).

MÜLLER-WIENER, W. (1998) Bizans'tan Osmanlı'ya İstanbul Limanı, trans. E. Özbek, Tarih Vakfı Yayınları, Istanbul (first published in German, 1993).

NECİPOĞLU, G. (2007) 15. ve 16. yüzyılda Topkapı Sarayı: mimari, tören ve iktidar, trans. R. Sezer, YKY, İstanbul (first published in English, 1991).

NICOL, D. (1992) Byzantium and Venice: a History of Diplomatic and Cultural Relations, Cambridge University Press.

NICOLLE, D., HOOK, A. (2005a) Crusader Castles in the Holy Land: 10971192, Osprey Publishing, New York.

NICOLLE, D., HOOK, A. (2005b) Crusader Castles in the Holy Land: 11921302, Osprey Publishing, New York. 
OBERHUMMER, E. (1902) Konstantinopel unter Sultan Suleiman dem Grossen, aufgenommen im Jahre 1559 durch Melchior. München.

OBOLENSKY, D. (1994) Byzantium and the Slavs, St Vlademir's Seminary Press.

OSTROGORSKY, G. (2002) The History of the Byzantine State, Rutgers, New Jersey.

OUSTERHOUT, R. (2008) Master Builders of Byzantium, University of Pennsylvania, Philadelphia.

The Oxford Dictionary of Byzantium, Oxford University Press, 1991.

ÖZASLAN, N. (1999) From the Shrine of Cosmidion to the Shrine of Eyüp Ensari, Greek, Roman and Byzantine Studies (40) 379-99.

ÖZTUNCAY, B. (2007) The Photographers Of Constantinople, 2 volumes, Koç Kültür, İstanbul.

PAMUKCIYAN, K. (1994) Depremler: Osmanlı Dönemi, İstanbul Ansiklopedisi, (3) 34.

PARTINGTON, J.R (1998) A History of Greek Fire and Gunpowder, The John Hopkins Press, Baltimore.

PERTUSI, A. (2006) İstanbul'un Fethi, Dünyadaki Yankısı, İstanbul Fetih Cemiyeti, İstanbul.

PRYOR, J., WILSON, P. (2007) The Chain of the Golden Horn 5-7 July 1203, In laudem hierosolymitani: studies in Crusades and medieval culture in honor of Benjamin Kedar, eds., I. Shagrir, R.Ellenblum, J.S. Riley-Smith, Ashgate, London.

PRYOR, J.H., JEFFREYS, E. eds. (2006) The Age Of The Dromon: The Byzantine Navy ca. 500-1204, Brill.

PRYOR, J. (1992) Geography, Technology and War: studies in the maritime history of the Mediterranean 649- 1571, University of Cambridge Press.

QUELLER, D., MADDEN, T. (1999) The Fourth Crusade: the Conquest of Constantinople, University of Pensylvania Press, Philadelphia.

Sai Mustafa Çelebi: Memories of Sinan and Architect Book of Buildings, Tezkiretü'l Bünyan ve Tezkiretü'l Ebniye, (2003) Koçbank, İstanbul.

SCHNEIDER, A.M., NOMIDIS (1944) Galata: Topographisch-Archaeologischer Plan mit erlauterdem text, İstanbul.

TALBOT, A.M., SULLIVAN, D. (2005) The History of Leo the Deacon: Byzantine Military Expansion in the Tenth Century, Dumbarton Oaks, Washington DC.

TANMAN, B. (1994) Kurşunlu Mahzen Köşkü, İstanbul Ansiklopedisi (5) 126-7.

THYS-ŞENOCAK, L. (2007) Ottoman Women Builders: the Architectural Patronage of Hadice Turhan Sultan, Ashgate.

Tournefort Seyahatnamesi (2005) trans. A. Berktay ve T. Tunçdoğan, Kitap Yayınevi, İstanbul.

TSANGADAS, B. (1980) Fortifications and Defense of Constantinople, Columbia University Press, New York.

ÜLGEN, A.S. (1939) Fatih Devrinde İstanbul, İstanbul. 
Alınd1: 03.02.2011; Son metin: 01.06.2011

Anahtar Sözcükler: Bizans'tan Osmanlı'ya İstanbul kent tarihi; kentsel kıyı bölgesinin tarihi; Haliç; Galata Hisarı; Kutsal Haç Kalesi; Kurşunlu Mahzen; Galata Gümrüğ̈̈; Yeraltı Cami.
VASILIEV, A.A. (1951) The Second Attack on Constantinople, Dumbarton Oaks Papers (6) 163-225.

VASILIEV, A.A. (1946) The First Russian Attack on Constantinople in 860, Medieval Academy of America, Cambridge MA.

WELLHAUSEN, J. (2004) Arab wars with the Byzantines in the Umayyad period, Arab-Byzantine relations in the early Islamic times, ed. Michael Bonner, Aldershot, Ashgate; 31-64.

YETIŞKİN KUBİLAY, A. (2009) Maps of Istanbul: 1422-1922, Denizciler Yayınevi, İstanbul.

\section{ALTINBOYNUZUN KÖŞESİ: GALATA KURŞUNLU MAHZEN ÜZERINNE MIMARİ BİR İNCELEME}

Altınboynuz olarak da bilinen Haliç'in, kuzeydoğu köşesini tarifleyen çok katmanlı bir anıt İstanbul'un kentsel kıyı bölgesinin mimarlık tarihini Bizans'tan Osmanlı'ya uzanan bir kesitte ilişiklendirir: Galata Hisarı; Haliç zincirinin bağlantı noktası; Yeraltı Camisi; ve Kurşunlu Mahzen. Mekanının tarihi önemiyle koşut olarak, bu çok isimli ve işlevli yapıya özgün ve ikincil kaynaklarda, gerek tekil gerekse de başka konular kapsamında, bol atıfta bulunulmuştur. Ne var ki, bu birikim mimari olarak yerindeki yapı kısımları ve kalıntılarının derinlemesine incelenmesi ve tarihsel gelişim üzerinden yeterince değerlendirilmemiştir.

Bu monografik yazı kaynaklar ve verileri Kurşunlu Mahzen'in tarihsel işlevleri bağlamında yeniden yorumlamaktadır: Liman hisarı, köprübaşı, silah mahzeni, un deposu, gümrük, kent girişi, cami ve karantina. Yapının tarihi dönemleri bu başlıklarda ortaya konurken, asıl konu sıradan bir askeri yapı tipolojisinin sıradışı dönüşümlerinin izlerinin sürülmesidir, ki bu farklı alanlarda karşılaştırmalı analizleri gerektirmiştir. Kurşunlu Mahzen'in nesnelleştirilmesi ve tarihi katmanlarının görselleştirilmesi yazının en belirgin katkılarındandır.

NAMIK ERKAL; B.Arch, M.Arch, Ph.D.

Assistant Prof. at the Department of Architecture, Middle East Technical University. His research topics are; urban form, architecture of defense, the architectural history of the markets and urban provisioning; specifically the harbors, customhouses and weighing centers of the Ottoman period. Has realized architectural projects specialized in new buildings in historical settings, such as the İstanbul Sakıp Sabancı Museum. 